\title{
Instrumentation, Methods, and Preliminary Evaluation of Evapotranspiration for a Grassland in the Arid Lands Ecology Reserve, Benton County, Washington, May-October 1990
}

By Stewart A. Tomlinson

\section{U.S. Geological Survey}

Water-Resources Investigations Report 93-4081

\section{Prepared in cooperation with}

STATE OF WASHINGTON DEPARTMENT OF ECOLOGY 
U.S. DEPARTMENT OF THE INTERIOR

BRUCE BABBITT, Secretary

U.S. GEOLOGICAL SURVEY

Gordon P. Eaton, Director

Any use of trade, product, or firm names is for descriptive purposes only and does not imply endorsement by the U.S. Government.

For additional information write to:

Copies of this report may be purchased from:

District Chief

U.S. Geological Survey

1201 Pacific Avenue - Suite 600

Tacoma, Washington 98402
U.S. Geological Survey

Earth Science Information Center

Box 25286, MS 517

Denver Federal Center

Denver, CO 80225 


\section{CONTENTS}

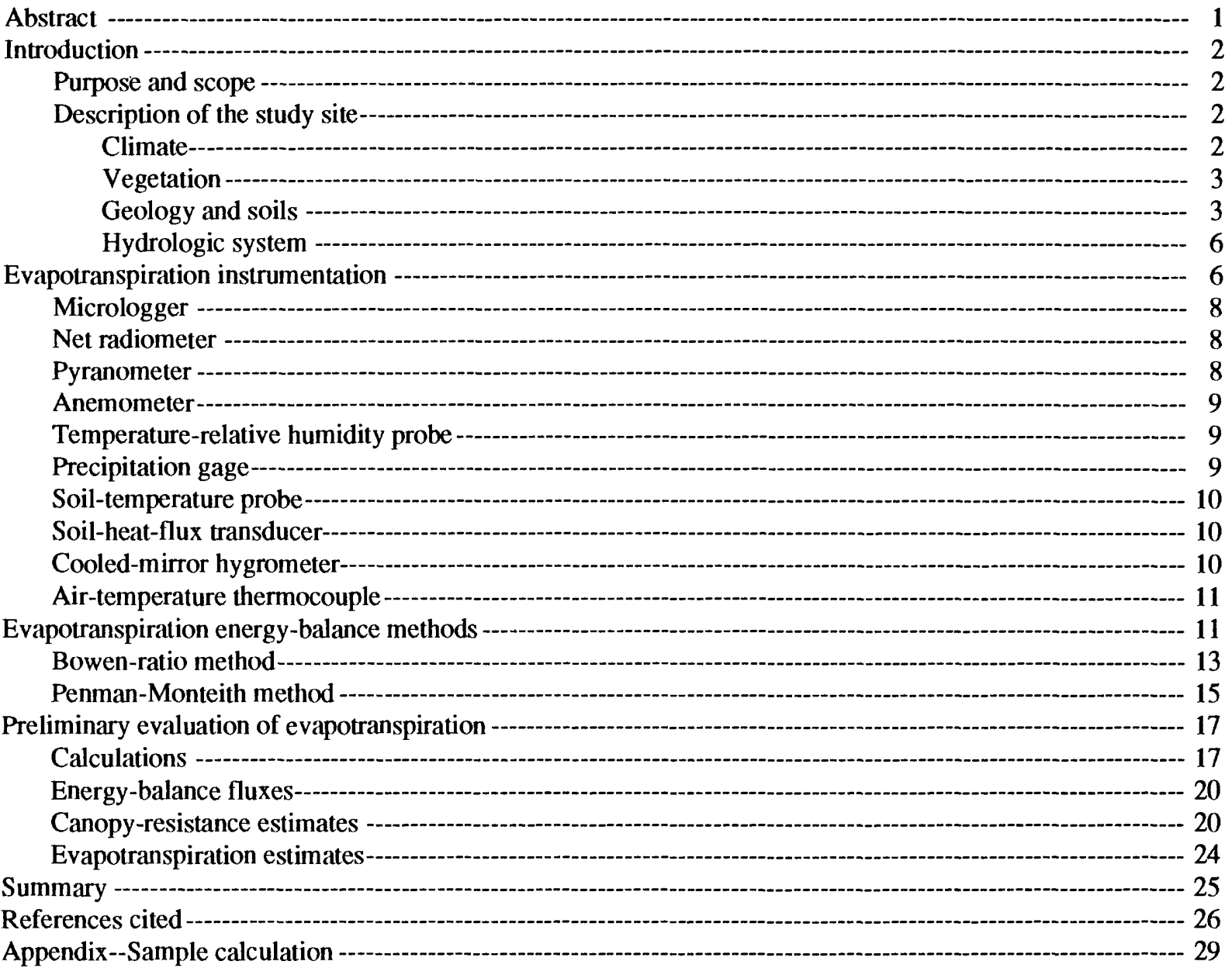

\section{FIGURES}

1. Map showing location of Snively Basin in Washington - - 4

2. Sketch showing instrumentation setup at Snively Basin site - 7

3. Schematic of energy budget for Snively Basin site - 12

4-6. Graphs showing:

4. Energy balance for Snively Basin evapotranspiration site -

5. A comparison of Bowen-ratio and Penman-Monteith latent-heat fluxes for Snively Basin

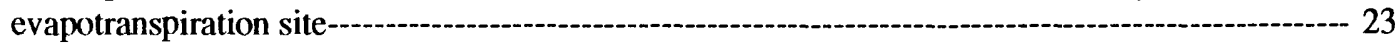

6. Daily Bowen-ratio and Penman-Monteith evapotranspiration for Snively Basin site, May 31 to October 15, $1990-$

\section{TABLES}

1. Daily and monthly precipitation, evapotranspiration, and canopy resistances for Snively Basin site, May 31-October 15, 1990 


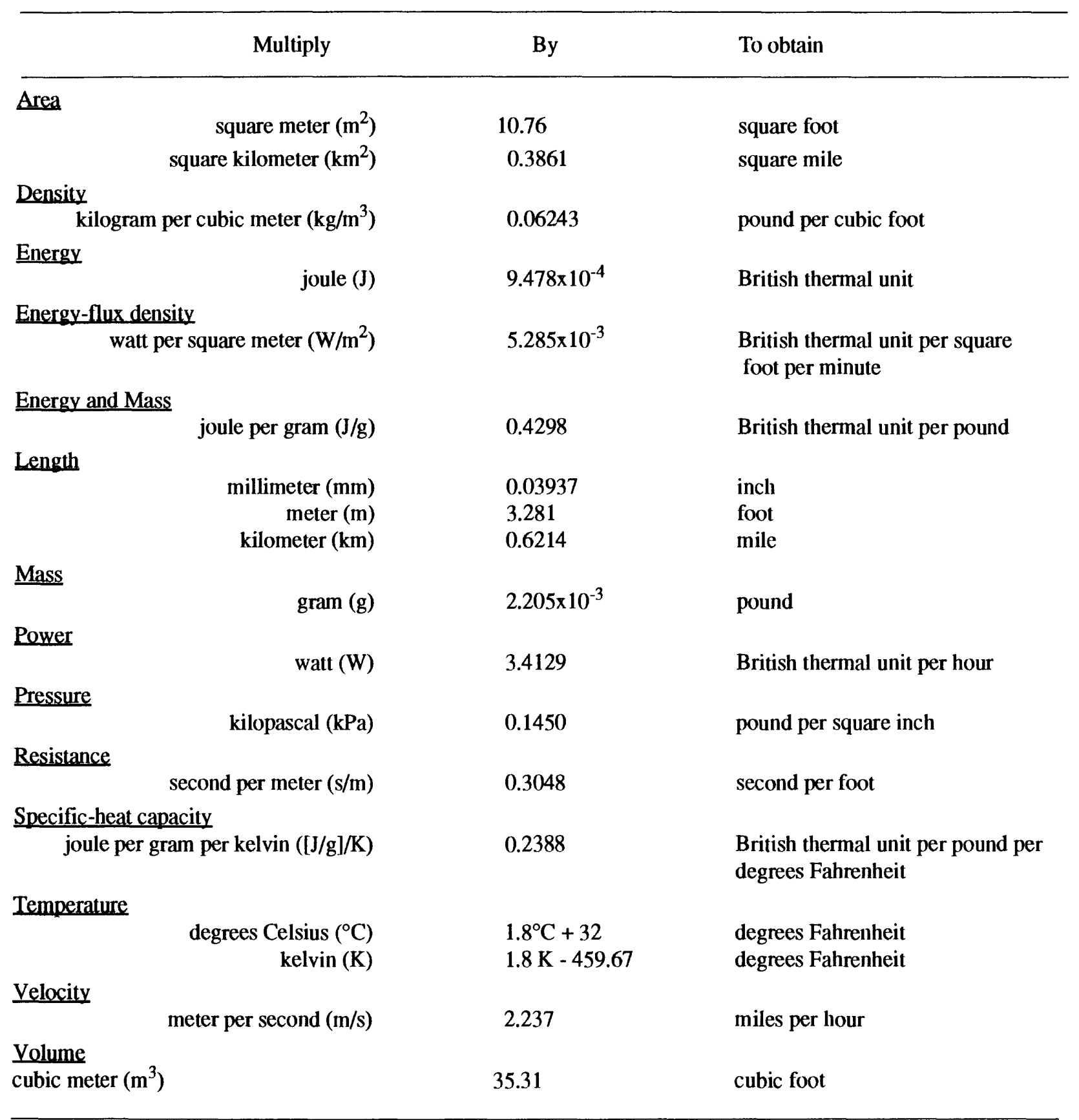

Sea level: In this report "sea level" refers to the National Geodetic Vertical Datum of 1929 (NGVD of 1929)-a geodetic datum derived from a general adjustment of the first-order level nets of both the United States and Canada, formerly called Sea Level Datum of 1929. 


\title{
Instrumentation, Methods, And Preliminary Evaluation of \\ Evapotranspiration For A Grassland In The Arid Lands Ecology Reserve, Benton County, Washington, May-October 1990
}

\author{
By Stewart A. Tomlinson
}

\begin{abstract}
This report describes the instrumentation, methods, and preliminary results for a study of evapotranspiration in a grassland in Snively Basin of the Arid Lands Ecology Reserve in south-central Washington. Instrumentation was used to collect data at the site from May 30 to October 15, 1990. Evapotranspiration was calculated by the Bowen-ratio and Penman-Monteith methods using collected data. Both methods are energy-balance approaches frequently used to estimate evapotranspiration for semiarid areas.
\end{abstract}

The Bowen-ratio method could be used to calculate estimates of latent-heat flux and evapotranspiration during only parts of the study period. Latent-heat flux values obtained during these periods were used to estimate the canopy resistance for use in the Penman-Monteith method. The Penman-Monteith method then was used to calculate evapotranspiration for the entire period of study. The canopy resistance directly affected the latent-heat flux and evapotranspiration estimates made with the Penman-Monteith method and was found to vary on a day-to-day basis. The canopy resistance ranged from near zero during periods of heavy rain to more than 40,000 seconds per meter during periods of extreme dryness.

Evapotranspiration estimates varied during the study period. Daily evapotranspiration generally ranged from 1 to 2 millimeters from May 30 to June 24 and from 0.2 to 1 millimeter from June 25 to July 25 . From July 26 through August 20, daily evapotranspiration was generally less than 0.4 millimeter as weather, soil, and vegetative conditions at the site became dry. On August 21, 28.19 millimeters of rainfall were measured at the Snively Basin site, resulting in daily evapotranspiration of more than 1 millimeter through August 23. From August 24 through September 2, daily evapotranspiration ranged from 0.3 to 0.9 millimeter. Progressive drying of soils resulted in daily evapotranspiration of less than 0.3 millimeter through October 13. The first rain of the autumn season fell on October 14, and the daily evapotranspiration rose to 1 millimeter through October 15. Monthly totals of evapotranspiration were as follows: June, 28.2 millimeters; July, 10.5 millimeters; August, 15.0 millimeters; September, 5.3 millimeters; and October 1-15, 1.8 millimeters.

The values of evapotranspiration calculated with the Bowen-ratio and Penman-Monteith methods are estimates. The complexity of data collection, data analysis, and canopy-resistance estimation for the Penman-Monteith method likely introduced some error into these estimates, particularly when daily evapotranspiration was near zero in August, September, and October. These errors may be small because during June and July, evapotranspiration calculated by the Bowen-ratio and Penman-Monteith methods agreed within about 25 percent on a daily basis and within 4 percent on a monthly basis. Variability in the daily and monthly evapotranspiration estimates between the two methods would likely be higher in August, September, and October, but these variabilities could not be quantified because the Bowen-ratio method could not be used to estimate evapotranspiration on most days during this period. 


\section{INTRODUCTION}

Evapotranspiration (ET), the quantity of water evaporated from soil and other surfaces plus the quantity of water transpired by plants, is a major part of the hydrologic cycle in semiarid south-central Washington. It is difficult to quantify because of the complexity of collecting accurate data needed to compute ET. Many environmental factors contribute to ET, each of which requires accurate measurement of a number of atmospheric variables under varied conditions. Some of these factors are particularly difficult to measure in semiarid areas; for example, extremes of temperature and relative humidity are occasionally beyond the data-collection specifications of available instruments. ET estimates, combined with precipitation and surface-water discharge data, are commonly used to estimate ground-water recharge (Gee and Kirkham, 1984; Gee and Hillel, 1988; Bauer and Vaccaro, 1990); thus, ET estimates are important to water-resource managers. In order to better estimate ET in semiarid eastern Washington, a cooperative ET project was established in August 1989 between the U.S. Geological Survey and the State of Washington Department of Ecology. The objectives of this project were to make long-term estimates of ET for a site in eastern Washington and to investigate a method requiring only standard meteorological, or easily collected, data for making those estimates.

\section{Purpose and Scope}

This report describes the methods and instrumentation used for ET research at a grassland site in the Arid Lands Ecology (ALE) Reserve in south-central Washington and presents preliminary estimates of ET for this site. A discussion of ET data-collection methods and instrumentation is combined with equations and variables needed to calculate ET to provide a single reference for this information that is important in understanding the ET process and problems associated with quantifying ET.

This report presents preliminary ET estimates for the ALE Reserve grassland site for 4-1/2 months from May 30 to October 15, 1990. A grassland site was chosen in Snively Basin of the ALE Reserve that provided suitable conditions for the use of energy-budget methods of estimating ET; uniform canopy height, flat to gently sloping aspect, and extensive cover. The methods used to estimate ET were the Bowen-ratio and Penman-Monteith methods. Data collected and used for the computations were net radiation, wind speed, air temperature, vapor pressure, relative humidity, soil temperature, soil heat-flux, and soil water content. Solar radiation and precipitation data also were collected for use in interpreting the other collected data, but were not required for the energy-budget calculations or ET computations.

\section{Description of the Study Site}

The study site lies within Snively Basin, located in the Rattlesnake Hills, on the ALE Reserve of the Hanford Site in western Benton County, Washington, about 64 kilometers east of Yakima and 40 kilometers west of Richland (fig. 1).

The ALE Reserve is characterized by flat to steeply sloping topography with altitudes ranging from about 134 meters in the lower valleys to 1,073 meters at the crest of the Rattlesnake Hills. Altitude of the site with instrumentation (study site) in Snively Basin is 494 meters. Major physiographic features dominating the surrounding area are the Columbia River to the north and east, the Yakima River to the south, and the Cascade Range about 160 kilometers to the west.

Many elements affect the ET process at the ALE Reserve and Snively Basin study site, including climate, vegetation, geology, soils, and the hydrologic system. Details of elements such as precipitation, vegetation makeup, soil type, and springflow are important in understanding ET at the study site.

\section{Climate}

The climate of the ALE Reserve is semiarid, primarily as a result of the rain-shadow effect produced by the Cascade Range. West of the Cascades, Olympia receives about 1,270 millimeters of precipitation annually, whereas east of the Cascades. Yakima receives only about 203 millimeters a year (Ruffner and Bair, 1987).

Precipitation at the ALE Reserve from 1969 through 1980 was studied by Stone and others (1983) and ranges from about 165 millimeters per year in the lower elevations to more than 280 millimeters annually just north of the Rattlesnake Hills crest.

Though not a factor in site selection, the study site in Snively Basin is located in one of the wettest areas of the ALE Reserve. The average annual precipitation is estimated to be 245 millimeters from an average of three precipitation stations that are within 5 kilometers of the study site (Stone and others, 1983). More than 75 percent 
of the precipitation falls from October through April, about one fourth of it as snow. June to September is normally the driest time of year, though convective storms can produce as much as 20 percent of the annual precipitation during this period; for example, on August 21, 1990, a thunderstorm produced 28.19 millimeters of rain on the site.

Temperatures are primarily continental, but frequent storm fronts move in from the Pacific Ocean, mainly during the winter months, moderating temperatures and bringing precipitation. The nearest weather station, Hanford Meteorological Station, about 21 kilometers away and 270 meters lower in elevation than the study site (fig. 1), has an average annual temperature of 11.7 degrees Celsius. Measured temperature extremes at Hanford range from 46 degrees Celsius to -33 degrees Celsius.

The study site is located in an open area and is exposed to wind. From observations made at the Hanford Meteorological Station, June is the windiest month with an average wind speed of 4.1 meters per second. The months of October to January are the least windy with an average wind speed of less than 3.0 meters per second.

\section{Vegetation}

Vegetation nearly completely covers the study site in Snively Basin; there is almost no bare soil surface. The vegetation is composed primarily of a mix of western cheatgrass (Bromus tectorum), bluebunch wheatgrass (Agropyron spicatum), and Sandberg's bluegrass (Poa sandbergii). Cheatgrass, an invasive grass from Europe introduced to Washington about 1890 (Franklin and Dyrness, 1988), is the predominant species. The height of the grassland canopy is about 0.35 meter. Individual plants are spaced about 0.05 to 0.25 meter apart. Roots from the grasses typically extend into the soil about 0.20 meter, though some roots were found as deep as 1.1 meters. Franklin and Dyrness (1988) found that cheatgrass roots will penetrate as deep as 0.97 meter. Abandoned farm areas near the study site also support quantities of naturalized cultivated rye.

Other plants growing in small numbers with the grasses are rabbitbrush (Chrysothamnus nauseosus), bitterbrush (Purshia tridentata), and other annuals and perennials. Sagebrush (Artemesia tridentata) is rare at the study site, though it grows extensively in areas about 150 meters away. Sagebrush is a fire-sensitive species (Franklin and Dyrness, 1988), so its absence at the site, combined with the abundance of cheatgrass, suggests that a fire may have burned the land surface several years ago, possibly when fires burned large areas of the ALE Reserve in 1984 (Gee and Heller, 1985).

Small stands of riparian vegetation grow adjacent to springs near the site. Springflow in Snively Gulch supports small numbers of woody plants, including trees. Trees identified using a field text (Hayes and Garrison, 1960) included black cottonwood (Populus trichocarpa), common chokecherry (Prunus virginiana), Columbia hawthorne (Crataegus columbiana), several species of willow (Salix sp.), and the naturalized exotic, white poplar (Populus alba).

Vegetation at the site grows most rapidly during the winter and spring wet seasons. Maximum growth occurs from March to May, when ET is also expected to be at a maximum due to transpiration created by the growing vegetation. Drier summer weather, normally beginning in June, slows growth and ultimately causes the grasses to seed and perish or go dormant. Growth begins again in late summer or fall when the first major rain occurs.

\section{Geology and Soils}

The ALE Reserve lies within the Pasco Basin, a structural basin in a region of layered basalts, which are folded into a series of anticlines and synclines (Graham, 1981). The Rattlesnake Hills, an anticlinal structure, form the south and west borders of the Pasco Basin. A geologic map of the Pasco Basin (Rockwell International, 1979) shows the study area to be overlain by Holocene loess. This loess is predominantly composed of silts, but also includes some fine-grained sand and layers of volcanic ash. Other loess deposits in the area include minor Pleistocene and older loess lying above the maximum Spokane Flood level of about 330 meters. Basaltic bedrock underlies the loess.

Hajek (1966) describes three types of silt loams as the major soil types in and adjacent to Snively Basin study area. The predominant type is Ritzville Silt Loam, a dark grayish-brown silt-loam soil that develops under grassland from silty, wind-laid (eolian) deposits mixed with a small amount of volcanic ash. The soil is generally greater than 1.5 meters thick, though it may be as shallow as 0.8 meter. The Soil Survey Report of Benton County Area, Washington, (U.S. Department of Agriculture, 1971) describes the soil as having high water-holding capacity and good drainage, moderate permeability, and low runoff potential. This is the soil type found at the instrumentated study site in Snively Basin. 


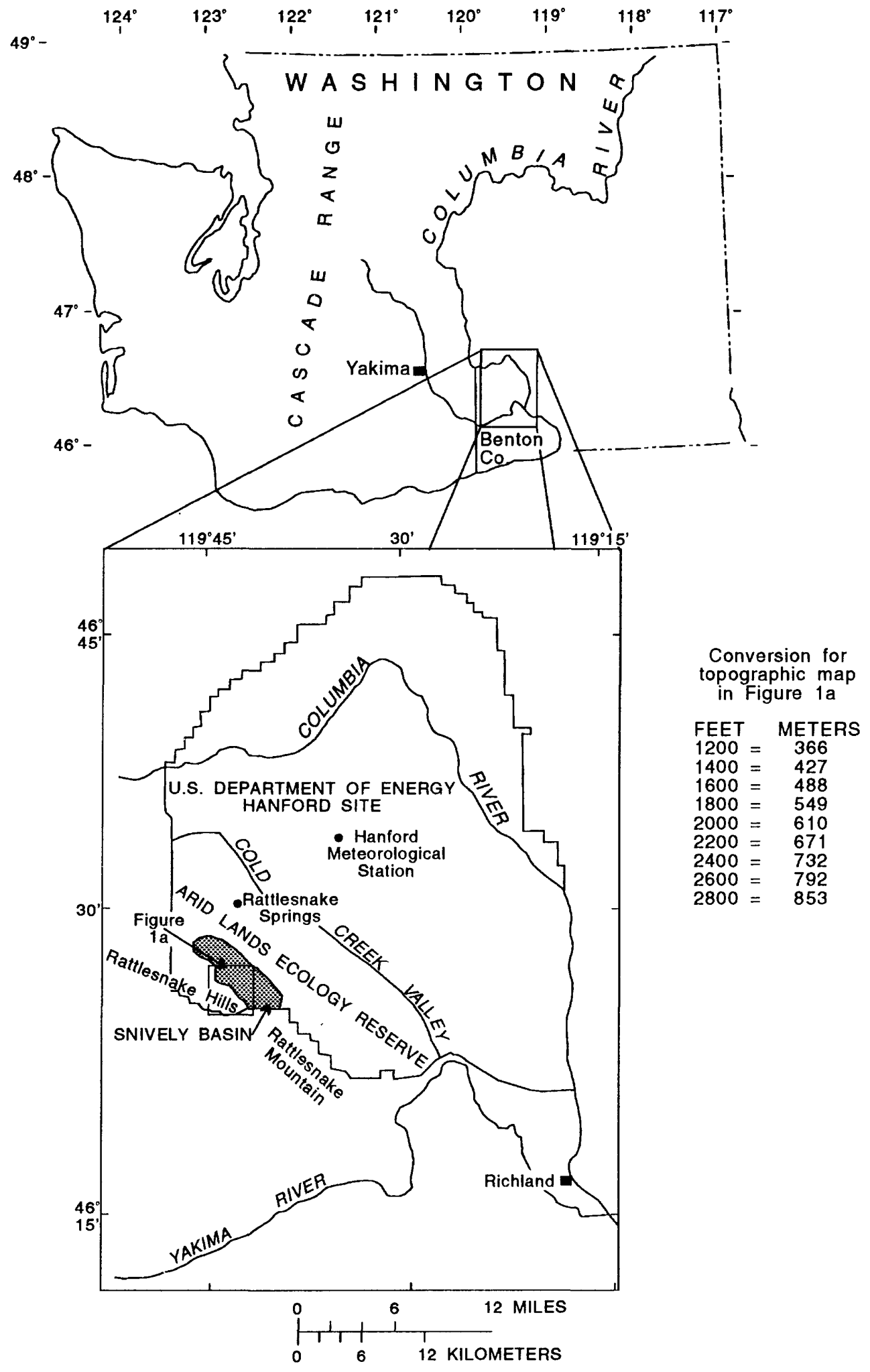

Figure 1.--Location of Snively Basin in Washington. 


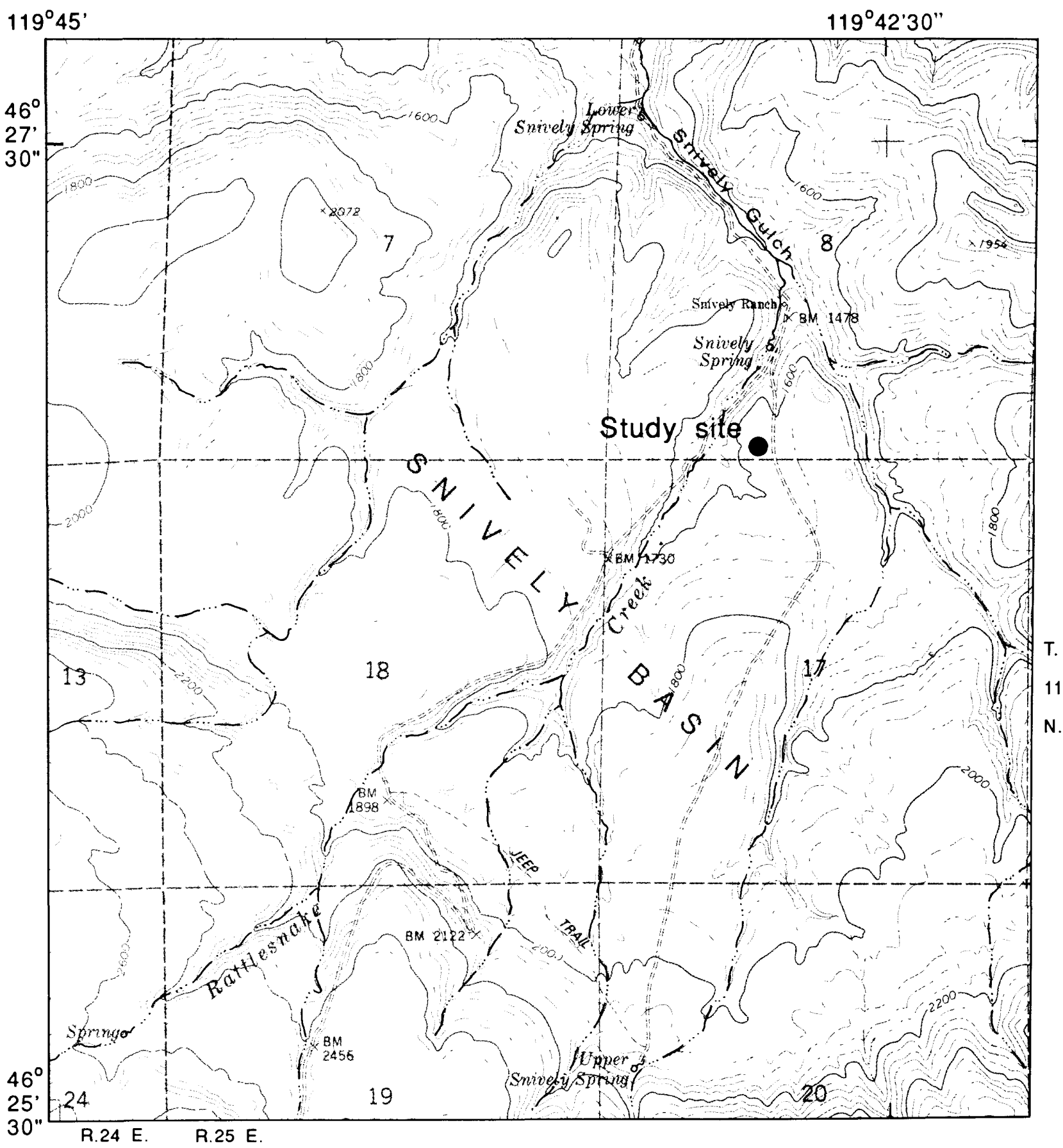

Base from U.S.Geological Survey Snively Basin, 1974

SCALE 1:24000

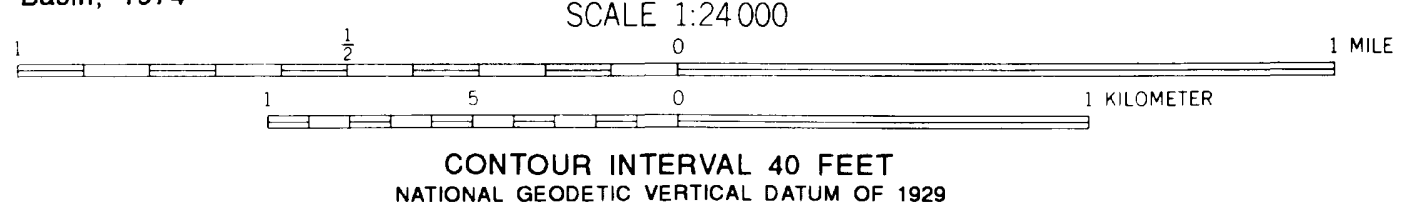

Figure 1a.--Location of study site in Snively Basin. 
The Warden Silt Loam is found in the lower part of Snively Basin. This soil differs from the Ritzville Silt Loam in that it becomes strongly calcareous at about 0.5 meter. The soil contains granitic boulders that were carried to the area with glacial ice by the Spokane Flood about 16,000 years ago. Warden Silt Loam developed under bunch grass from eolian deposits overlying older lakebed sediment (U.S. Department of Agriculture, 1971). This soil type predominates at altitudes slightly lower than the study site. Hajek (1966) reports that Warden soils intergrade to Ritzville soils at approximately 366 meters, just below the study site altitude of 494 meters.

Lickskillet Silt Loam occupies ridgetops in Snively Basin above the study site beginning at about 762 meters (Hajek, 1966). This very thin, stony soil overlies basaltic bedrock.

\section{Hydrologic System}

Major processes of the hydrologic system on the ALE Reserve include precipitation, ET, ground-water storage and recharge, and surface-water runoff. Most precipitation that falls is lost to ET. For a site on the Hanford Site lower in altitude than the study site, Gee and Jones (1985) reported that of $150 \pm 100$ millimeters of precipitation, $150 \pm 50$ millimeters were lost through ET.

Very little of the annual precipitation becomes ground water. In a water-balance study at Hanford, Gee and Kirkham (1984) reported that 50 millimeters of water penetrated 3.5 meters below a grass-covered land surface in 1983, a wet year with more than 280 millimeters of precipitation. During dry years, such as 1976 , Hanford receives as little as 76 millimeters of precipitation (Stone and others, 1983) and probably little, if any, of this becomes ground water. Link and others (1990) found that grass-covered areas of the ALE Reserve held more water at a depth of 2.75 meters than areas covered with sagebrush. Consequently, grass-covered areas, such as the study site, would be expected to allow more recharge than areas covered with the deeper-rooted sagebrush, which would remove more deeply stored water. Because fire removes sagebrush and encourages grass to flourish, it is an important factor in facilitating recharge to subsurface layers.

Many springs flow on the ALE Reserve. Schwab and others (1979) described 125 springs in the area and found flows ranging from small seeps with instantaneous discharges of less than $1.6 \times 10^{-5}$ cubic meters per second (one-quarter gallon per minute) to multiple spring streams with measured flows of $4.4 \times 10^{-3}$ cubic meters per second (70 gallons per minute). Subsurface flows from these springs and upper-elevation snowmelt recharge a perched water table that is about 30 meters above the static water table, in the lower altitudes of the ALE Reserve (Harr and Price, 1972). No water-table information is available at the study site.

Snively Basin has several springs, the largest being Lower Snively Spring with an instantaneous flume-measured flow estimated at $2.8 \times 10^{-3}$ cubic meters per second; (45 gallons per minute; Schwab and others, 1979). The spring system is fairly complex, with flows disappearing below the land surface and reappearing in other areas lower in altitude. These springs are the primary surface runoff except during and shortly after intense rainfall. The study site in Snively Basin is located about 1 kilometer from these springs.

\section{EVAPOTRANSPIRATION INSTRUMENTATION}

Two sets of instrumentation collected data at the study site in Snively Basin (fig. 2). One set collected data primarily used to calculate ET using the Bowen-ratio method. The second set collected data primarily used to calculate ET using the Penman-Monteith method. The Bowen-ratio set of instrumentation included one micrologger, one net radiometer, one set of four soil-temperature probes, two soil-heat-flux transducers, one cooled-mirror hygrometer with two vapor-pressure intakes, and two airtemperature thermocouples. The Penman-Monteith set of instrumentation included one micrologger, one net radiometer, one pyranometer, one anemometer, one temperature/relative-humidity probe, one precipitation gage, one set of four soil-temperature probes, and two soil-heat-flux transducers. Additionally, field personnel collected soil samples during site visits in order to determine soil moisture for use in calculating the soil-heat storage term for Bowen-ratio and Penman-Monteith methods.

Separate tripods and masts held each set of instrumentation. The soil-heat-flux plates and soil-temperature probes lay below the soil surface. Field personnel installed both sets of instrumentation on May 30, 1990, and visited the field site about every 2 weeks. The Bowen-ratio set of instrumentation was disassembled by field personnel on October 15, 1990, and stored for the winter because of the sensitivity of the cooled-mirror hygrometer to freezing temperatures. 


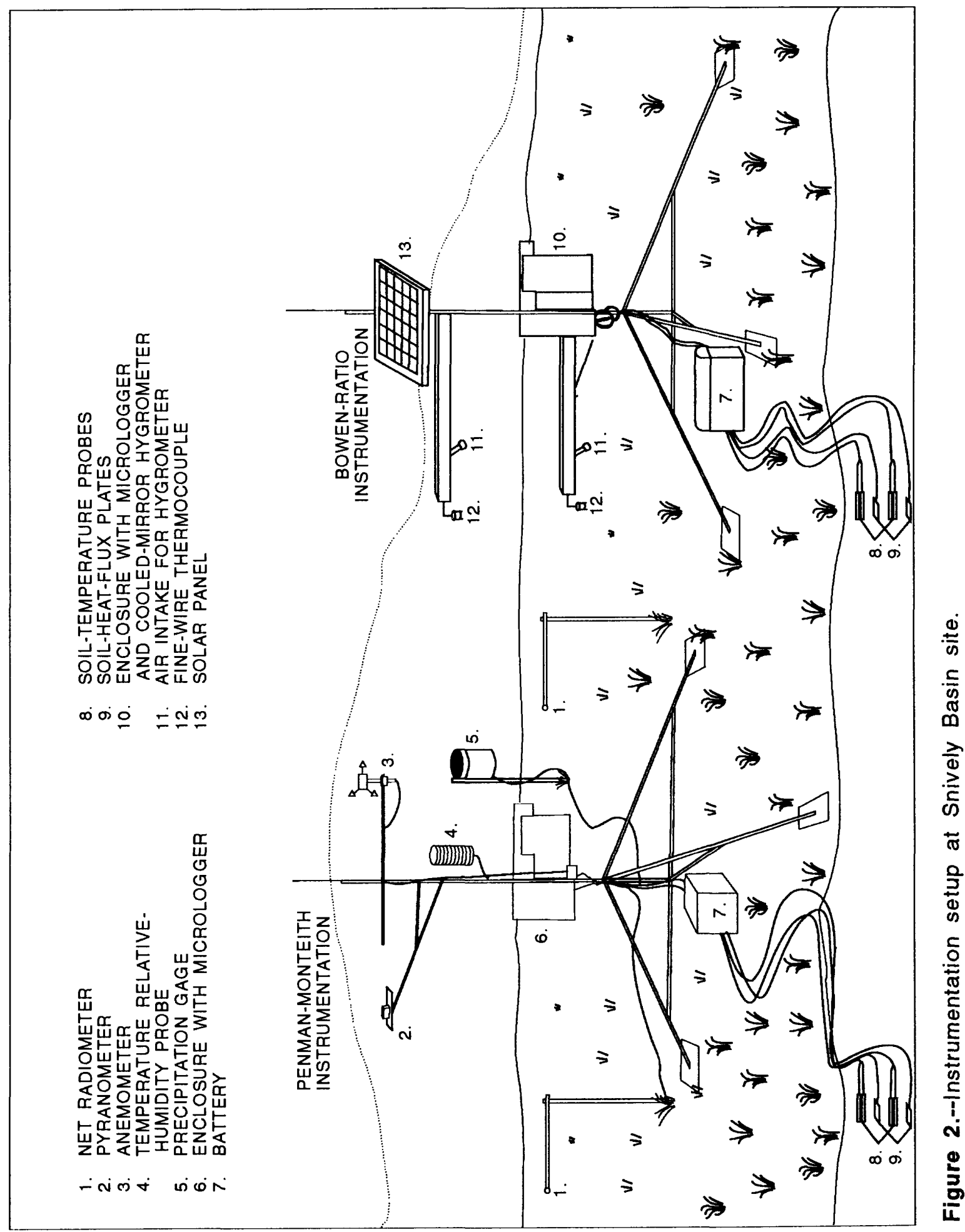


Several problems with the instrumentation resulted in incomplete or erroneous data. Burrowing animals chewed the soil-heat-flux transducer wires on several occasions. The motor driving the pump for the cooled-mirror hygrometer ran intermittently from about June 25 to July 10. The pump was replaced July 11. On August 21, a storm with heavy rain, possibly hail, broke the lower fine-wire thermocouple. The thermocouple was replaced September 6.

\section{Micrologger}

Separate Campbell Scientific 21X microloggers recorded data from each instrument set. These will be referred to as the Bowen-ratio micrologger and the Penman-Monteith micrologger.

The Bowen-ratio micrologger sampled air temperature and vapor pressure instruments every second, net radiation, soil-heat flux, and soil temperature every 10 seconds, and calculated 20-minute averages for each for the entire study period. A 105 amp-hour photovoltaic battery powered by an 18-watt solar panel supplied continuous power for the micrologger and cooled-mirror hygrometer.

The Penman-Monteith micrologger scanned instruments every 10 seconds and calculated and stored averages for all instruments except the precipitation gage, for which totals were stored. The micrologger calculated averages, or totals, for 60-minute periods from May 30 to July 31 and for 20-minute periods from August 1 to October 15. An external 8 amp-hour battery, replaced during each site visit, powered the micrologger and associated instruments. An internal battery pack supplied backup power during replacement of the external battery.

Both microloggers transferred data to storage modules, which were collected and replaced by field personnel during each site visit. Personnel downloaded data from the modules to a microcomputer, where ET computations and analyses were performed.

\section{Net Radiometer}

Net radiation was measured with a Radiation and Energy Balance Systems (REBS) Q-6 net radiometer. Net radiation is defined as the sum of all incoming shortwave solar radiation and incoming longwave sky radiation minus the sum of reflected solar radiation and emitted longwave radiation (Haan and others, 1982).
The manufacturer's manual provides the following information. The Q-6 net radiometer consists of a high-output, 62-junction thermopile with a nominal resistance of 4 ohms. Polyethylene domes, 0.25 millimeter thick, protect the black and white sensing surfaces from convective cooling. The size of the black and white sensing surfaces balances longwave and shortwave sensitivities. Sensing surfaces within the domes connect to a support arm 0.75 meter long. A 1-degree bubble level on the instrument is used to maintain the sensing surface in a horizontal position.

The net radiometer, positioned 1 meter above the height of the vegetative canopy, maintains a relatively unobstructed view of the surrounding landscape. The instrument requires no power to work. A voltmeter in the micrologger having a 10-microvolt resolution and range of -10 to 75 millivolts from the net radiometer monitors the output. The micrologger multiplies the thermopile voltage by a calibration factor determined by the manufacturer to obtain the net radiation in watts per square meter.

To maintain the net radiometer, field personnel periodically cleaned the polyethylene domes with distilled water and a soft cloth and replaced the domes when they became broken, cracked, or noticeably opaque. In addition, they checked the net radiometer bubble levels during every site visit to assure the net radiometers were in a horizontal position.

\section{Pyranometer}

A pyranometer measures global solar (shortwave) radiation, which includes direct solar radiation plus sky, or diffuse, radiation. The pyranometer used in this project, the LI-COR LI-200S pyranometer, uses a silicon photodiode accurate to plus or minus 5 percent over a range of zero to 3,000 watts per square meter. A 100 -ohm resister converts the output of the instrument, about 80 microamps per 1,000 watts per square meter, to voltage. Data from this instrument provided a source for estimating net radiation in the event the net radiometer became inoperative.

The sensor mounts on a level base positioned 3 meters above the canopy, though the height is not of great importance. The micrologger receives voltage output from the pyranometer and multiplies it by a factory-determined calibration factor to convert output to watts per square meter. 
To maintain the pyranometer, field personnel checked the bubble level on the base fixture of the pyranometer to assure it maintained a horizontal position and cleaned dust and debris from the pyranometer. The manufacturer recommends that the sensor be recalibrated every 2 years.

\section{Anemometer}

The anemometer measures wind speed. The type used in the study was a Met One 014A anemometer, a 3-cup anemometer with a magnet-activated reed switch whose frequency is proportional to wind speed. According to the manufacturer, the range of the instrument is 0.447 to 45 meters per second and accuracy is plus or minus 1.5 percent over this range.

The owner's manual for the anemometer provides the following information. The cups, constructed of aluminum, mount on a cup-assembly head connected to a stainless steel shaft. The shaft rotates on precision ball-bearings and connects the cup assembly to the magnet assembly. When the shaft rotates, the turning magnet assembly causes a reed switch to close. There are two reed switch closures per revolution. The frequency of the reed switch closure is linear from the threshold speed of 0.447 meters per second to 45 meters per second. The micrologger counts the switch closures and gives the wind speed in meters per second.

Field personnel inspected the anemometer during each site visit for signs of cracks or loose connections. After 1 year of service, the manufacturer recommends replacing the sensor ball-bearings. After 2 years, they suggest complete factory overhaul of the sensor.

\section{Temperature-Relative Humidity Probe}

The temperature-relative humidity probe used, a Campbell Scientific 207 temperature and relative humidity probe, consists of two sensors. The first, a thermistor, measures air temperature on the basis of resistance changes occurring in the thermistor as the air temperature changes. The second sensor, a relative-humidity chip, measures changes in resistance with changes in relative humidity. A polystyrene radiation shield houses both sensors.

According to manufacturer specifications, the temperature sensor is accurate to plus or minus 0.4 degrees Celsius over the range of -33 degrees Celsius to 48 degrees Celsius. The relative-humidity sensor typically is better than plus or minus 5 percent over its 12 percent to 100 percent relative-humidity range; if the relative humidity drops below 12 percent, the sensor gives less accurate readings. The relative humidity only seldom drops to such levels at the field site, as values from the cooled-mirror hygrometer indicated.

The sensors and shield mount on a mast at 2 meters above the canopy. Field maintenance consists of removing dust and debris from the surface of the radiation shield. Because extremely wet weather and air pollution will, in time, deteriorate the relative-humidity sensor, relative-humidity chips are replaced annually as the manufacturer recommends.

The micrologger sends a 4-volt excitation to the temperature-relative humidity probe to produce the voltage drop across the resistor in each sensor. This provides an output in degrees Celsius and percentage of relative humidity.

\section{Precipitation Gage}

The precipitation gage used in the study was a Texas Electronics TE525 tipping-bucket rain gage, a miniature adaptation of the standard U.S. Weather Bureau tippingbucket electric rain gage. The following information is derived from the owner's manual for the precipitation gage. A collector funnel, topping the instrument, diverts water to a tipping-bucket mechanism. A magnet attaches to the tipping bucket. As the bucket tips, the magnet drives a high-current magnetic switch that closes for 135 milliseconds and activates the counter in the micrologger. Water then drains from the bottom of the bucket enclosure. Resolution of the instrument can be set to 0.1 millimeter or to 0.01 inch. Data from the precipitation gage were used to help determine the canopy resistance in the Penman-Monteith analyses.

The tipping-bucket electric rain gage can be mounted in several ways. For this project, the rain gage mounted a mast at a height of about 1.5 meters above the canopy. The rain gage generally required no maintenance. Field personnel removed some dust and debris from the gage during extended dry periods. 


\section{Soil-Temperature Probe}

Two Campbell Scientific TCAV averaging soil thermocouple probes, located above each of two soil-heat-flux transducers, obtained a spatial-average soil temperature for the area above the soil-heat-flux transducers. The probes were composed of 40-gauge chromel-constantan.

Correct placement of the temperature probes, as well as of the flux transducers, requires an undisturbed soil layer. A shovel was used to cut a vertical section down in the soil and the section was removed intact. Two temperature probes were then placed horizontally in the undisturbed face. In this study, flux transducers were placed at a depth of 5 centimeters, one probe was set at a depth of 1.7 centimeters, and a second at 3.3 centimeters. Burying 0.6 meter of the sensor lead wire length minimized thermal conduction down the sensor lead wires. Replacing and compacting the section of soil removed air pockets.

The micrologger converted the average voltage reading from the soil-temperature probes to temperature. Averages were used to obtain the average temperature of the top 5 centimeters of soil.

\section{Soil-Heat-Flux Transducer}

The heat-flux transducer, or soil-heat-flux plate, used was a REBS HFT-1 heat-flow tranducer, a high-output, low-resistance thermopile designed to measure heat flow in soils. High-thermal-conductivity epoxy shields the thermopile and prevents ground-potential interference. The thermopile has a nominal resistance of $2 \mathrm{ohms}$.

The heat-flux transducer was installed level in the soil at 5 centimeters below the soil surface. At this depth, the plate retards soil-moisture migration only slightly and gives representative heat-flow measurements for the surrounding soil. Using two heat-flux transducers, set about 15 centimeters apart, assured a representative average. The micrologger multiplied the thermopile voltage readings from each transducer by a factory-determined calibration factor to give the heat flux in watts per square meter.

Generally the heat-flux transducers required little maintenance. Field staff periodically checked the wires for signs of wear or breaks. Also, once a year the transducers were returned to the manufacturer for recalibration.

\section{Cooled-Mirror Hygrometer}

The unit used for this study was Campbell Scientific Model 023 Bowen-ratio enclosure with hygrometer and flow controller, whose main component is the General Eastern Model DEW-10 cooled-mirror hygrometer. Tanner and others (1987) developed the cooled-mirror hygrometer design for making vapor-pressure measurements with minimum maintenance in remote areas. Dry-and-wet-bulb psychrometers commonly measure vapor pressure. However, problems related to wick-wetting and water supply limit their use in arid and semiarid areas, such as the study site. Because the cooled-mirror hygrometer does not need a constant source of water, it was chosen for this project.

According to the manufacturer's manual, the system works as follows. A single low-power pump alternately draws air through two intakes to a metallic mirror, which is cooled by a miniature heat pump. The air moves at a rate of 0.4 liter per minute through 2-liter mixing containers to extend the time constant of vapor measurement to 5 minutes. When the mirror reaches the dew point of the air, a thin layer of dew condenses on the mirror surface. The instrument optically detects this layer while a feedback loop keeps the mirror at the dew point by continuously controlling the mirror temperature. A small sensor embedded just beneath the surface of the mirror allows the dew-point temperature to be measured accurately.

The aspirating pump draws air to the mirror alternately from two heights through intakes containing 1-micrometer pore size Teflon filters designed to prevent liquid water and dust from contaminating the lines, mixing chambers, and mirror. The pump draws air from one intake for 2 minutes, then switches to the other intake for 2 minutes. A set of in-line rotameters blocks the air flow to the mirror from the intake not being measured. The mirror stabilizes at the new dew point for 40 seconds, then the micrologger takes measurements for 1 minute and 20 seconds. The micrologger measures the dew-point temperature every second and uses it to calculate vapor pressure. The micrologger averages the vapor pressure for each intake height every 20 minutes.

An 18-watt solar panel connected to a 105-ampere photovoltaic battery powered the cooled mirror, aspirator pump, and micrologger. Maintenance consisted of replacing the Teflon intake filters and cleaning the mirror with a cotton swab wetted with a lens-cleaning solution. Also, field personnel checked and readjusted, if necessary, the 
bias adjustment of the mirror following procedures outlined by the manufacturer of the cooled-mirror hygrometer.

Although the system is fairly straightforward to operate and maintain and works well within its designed standards, there are some limitations to its use. The cooled-mirror hygrometer works most accurately in the range of about 10 to 90 percent relative humidity. Also, it can only measure a dew point that is not more than 40 degrees Celsius different from the ambient temperature. Under extremely hot, dry environmental conditions, the range of the instrument can be exceeded, producing erroneous data. This situation was not a major problem in the study area, but it has been a problem noted in slightly more arid areas at higher elevations (W.D. Nichols, U.S. Geological Survey, oral commun., 1990).

Very dry conditions in August, September, and October did, however, make collection of accurate vaporpressure data difficult. Many erroneous data were noted during this period even when relative humidities were within the range of the instrument. The reason for the poor-quality vapor-pressure data collected during these months is not known.

A frequent problem toward the end of the study period was the formation of ice on the cooled mirror. This happened when the dew point of the ambient air fell well below freezing for several hours, usually in the early morning. Generally, warmer air during mid to late morning melted the ice and allowed the cooled mirror to resume normal operation. Occasionally, the ice did not melt completely and caused the instrument to produce erroneous data.

\section{Air-Temperature Thermocouple}

Campbell Scientific FWTC-1 and FWTC-3 Type E fine-wire thermocouples measured air temperature at two heights. Each chromel-constantan thermocouple consists of two parallel 25-micrometer (FWTC-1) or 76-micrometer (FWTC-3) diameter junctions between two leads. The leads form a $V$ shape and the junctions are attached to the inside legs of the V. The 25-micrometer types were used initially because of their low capability for radiation loading. These connectors proved too fragile for field use, however, and broken connections were replaced with 76-micrometer connections by the manufacturer. These still have fairly low radiation-loading potential and are much sturdier for outdoor use.
The thermocouples mount 1 meter and 2 meters above the canopy at the end of 1-meter long metal arms, which also house intakes and tubing for the water-vapor measurements. Wire leads connect the thermocouples to the micrologger, which averages temperature readings in degrees Celsius for each height over a 20-minute output interval.

For maintenance, field personnel checked the connections for any breaks and cleaned dust and spider webs off the thermocouples. If they observed a broken connection, they replaced the entire thermocouple and sent the damaged one to the manufacturer for repair.

\section{EVAPOTRANSPIRATION ENERGY-BALANCE METHODS}

ET involves a phase change of water from liquid to vapor, a process requiring energy, and the movement of that vapor into the atmosphere. It can be conceptualized as taking place as part of an energy budget that has four main components: net radiation, latent-heat flux, sensible heat flux, and soil-heat flux. Field measurement of the energy budget components involve establishing a horizontal layer with an upper boundary just above the plant canopy and a lower boundary just below the soil surface (fig. 3). Brutsaert (1982, p. 2) gives the energy budget equation as:

$$
R_{n}=L E+H+G
$$

where

$R_{n} \quad=$ net radiation,

$L E \quad=$ latent-heat flux,

$H \quad=$ sensible-heat flux, and

$G \quad=$ soil-heat flux.

These energy fluxes, as they are commonly called, are energy-flux densities ("flux" is used to mean "flux-density" throughout this report) which represent energy flow per unit horizontal surface area. In this report, all energyflux values are in watts per square meter. Use of the energy-budget equation assumes that horizontal advection of energy and change of energy stored in the plant canopy are negligible.

Net radiation, defined as the sum of all incoming shortwave solar radiation and incoming longwave sky radiation minus the sum of reflected solar radiation and 


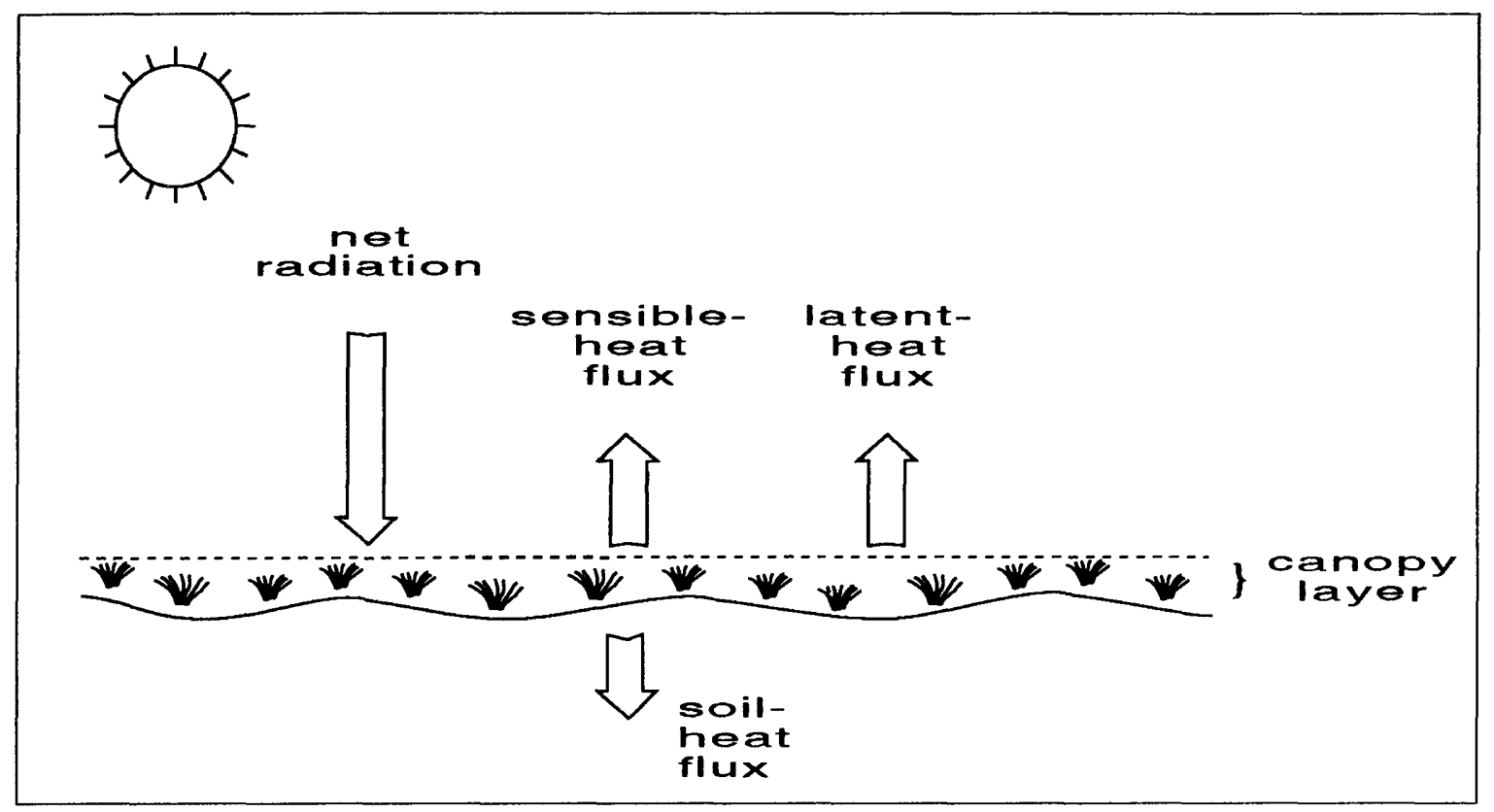

Figure 3.--Schematic of energy budget for Snively Basin site.

emitted longwave radiation (Haan and others, 1982), provides the energy source for the energy-budget equation. Net radiation is considered positive when the incoming solar radiation crossing down through the upper boundary of the canopy layer toward the land surface exceeds the solar radiation reflected up through the canopy layer.

The latent-heat flux, $L E$, is the product of $L$, the latent-heat of vaporization of water (the amount of energy required to change 1 gram of liquid water to vapor at constant temperature), and $E$, evapotranspiration expressed as a mass flow per unit horizontal area. $L$, in joules per gram, is a function of temperature and can be described (W.D. Nichols, U.S. Geological Survey, oral commun., 1990) by the equation

$$
L=\frac{\Re[6,788.6-5.0016(T+273.15)]}{\varepsilon},
$$

\section{where}

$\Re=0.28704$, a gas constant for dry air, in joules per gram per kelvin ( $[\mathrm{J} / \mathrm{g}] / K)$,

$T=$ temperature, in degrees Celsius (converted to Kelvin in equation 2 through +273.15 ), and

$\varepsilon \quad=0.622$, the ratio of molecular weight of water to air.
The values $6,788.6$ and 5.0016 are empirically determined constants. Equation 2 can be reduced to

$$
L=2,502.3-2.308 T \text {. }
$$

For equations 2 and 3, $T$ is the temperature of the evaporating surface, in degrees Celsius. Air temperature was assumed to be representative of the surface temperature, and was used in this study to determine $L$.

Sensible-heat flux, $H$, in equation 1 is the energy-budget component derived from surface heating. It is the transfer of energy between the surface and the atmosphere caused by a temperature gradient. This term is considered positive when heat is transferred upward across the upper boundary of the canopy layer.

Soil-heat flux is defined as the amount of energy moving downward through the soil from the land surface, caused by temperature gradient. Soil-heat flux is considered positive when moving down through the soil from the land surface and negative when moving upward through the soil toward the surface. Because soil-heat flux is measured below the soil surface, some of the energy crossing the soil surface could be stored in, or come from, the layer of soil between the surface and the point of measurement. 
Therefore, a change in storage term, $S$, must be added to the measured heat flux. This storage term is calculated (Campbell Scientific, Inc. 1991, section 4, p. 3) by the equation

$$
S=\left(\frac{\Delta T_{s}}{\Delta t}\right) d \rho_{b}\left[C_{s}+\left(W C_{w}\right)\right],
$$

where

$S \quad=$ flux going into storage as soil heat, in watts per square meter,

$\Delta t=$ time interval between measurements in seconds,

$\Delta T_{s}=$ soil-temperature difference over time interval, in degrees Celsius,

$d \quad=$ depth to soil-heat-flux plates, in meters,

$\rho_{b} \quad=$ bulk density of dry soil, in kilograms per cubic meter,

$C_{s} \quad=$ specific heat of dry soil, in joules per kilogram per degrees Celsius, $([\mathrm{J} / \mathrm{kg}] / \mathrm{C})$

$W \quad=$ water content of soil, in kilograms of water per kilograms of soil, and

$C_{w}=$ specific heat of water, in joules per kilogram per degree Celsius, $([\mathrm{J} / \mathrm{kg}] / \mathrm{C})$.

The soil-heat flux at depth $d$ was averaged from measurements made by two soil heat-flux plates at depth $d$. The soil-heat flux at the surface is obtained by including the effect of storage between the surface and depth $d$, and is given by

$$
G=\left(\frac{F X 1+F X 2}{2}\right)+S
$$

where

$$
\begin{aligned}
& F X 1=\text { soil-heat flux measurement } 1 \text {, in watts per square } \\
& F X 2=\text { soil-heat flux measurement } 2 \text {, in watts per square }
\end{aligned}
$$

and other terms are as described previously.

This paragraph and the following paragraph, adapted from D.I. Stannard, U.S. Geological Survey (written commun., 1990), describe how net radiation functions to drive the other fluxes. During daylight hours, net radiation warms the land and vegetated surfaces. The warmed surface transmits heat to the overlying air and to the soil below. The evaporation of liquid water requires energy, and also removes heat from the land and vegetated surface.

At night, net radiation changes direction and becomes negative. As the soil and vegetated surfaces cool, the soil-heat flux and sensible-heat flux change direction and become negative. If air temperature drops below the dew point, dew forms, releasing the heat of condensation and causing the latent-heat flux to change direction, becoming negative.

The energy-balance methods used to calculate the four energy-budget components and ET were the Bowen-ratio method and the Penman-Monteith method. These methods have been widely used in ET and water-budget research. The theory associated with these methods, the assumptions made in using each of them, and the elements involved with each are important in understanding how the energy-budget and ET estimates were made.

\section{Bowen-Ratio Method}

Bowen (1926) defined the ratio of sensible and latent-heat fluxes of the energy-budget equation, known as the Bowen ratio, $\beta$. He showed that this ratio, described by

$$
\beta=\frac{H}{L E},
$$

could be calculated from vertical gradients of temperature and vapor over a surface under certain conditions. Often the gradients are approximated from air temperature and vapor pressure measurements taken at two heights above the canopy. The vertical sensible-heat flux, $H$, is a linear function of the vertical temperature gradient described in Rosenberg and others (1983, p. 255) by

$$
H=P C_{p} K_{h}\left(\frac{d T}{d z}\right),
$$


where

$P=$ atmospheric pressure in kilopascals,

$C_{p}=$ specific heat of air, equal to 1.005 joules per kilogram per degree Celsius,

$K_{h} \quad=$ height-dependent exchange coefficient for heat transport, unitless,

$T=$ air temperature in degrees Celsius, and

$z=$ measurement height, in meters.

Similarly, the vertical latent-heat flux, $L E$, is a linear function of the vertical vapor-pressure gradient described by Rosenberg and others (1983, p. 255) by

$$
L E=L \quad \varepsilon \quad K_{w}\left(\frac{d e}{d z}\right)
$$

where

$$
\begin{aligned}
& L=\text { latent heat of vaporization in joules per gram, } \\
& \varepsilon \quad=\text { ratio of molecular weight of water to dry air, } \\
& \text { equal to } 0.622 \\
& K_{w}=\text { height-dependent exchange coefficient for water } \\
& \text { vapor transport, unitless, } \\
& e \quad=\text { vapor pressure in kilopascals, and } \\
& z \quad=\text { measurement height in meters. }
\end{aligned}
$$

Dividing equation 7 by 8 , the Bowen ratio can be expressed as

$$
\beta=\frac{P C_{p} K_{h}\left(\frac{d T}{d z}\right)}{L \varepsilon K_{w}\left(\frac{d e}{d z}\right)} .
$$

Because the exchange coefficients for heat and water vapor transport, $K_{h}$ and $K_{w}$, respectively, are assumed equal under many conditions (Tanner, 1988), and the term $(d T / d z) /(d e / d z)$ is approximately equal to $\Delta T / \Delta e$, equation 9 can be simplified to

$$
\beta=\frac{P C_{p} \Delta T}{L \varepsilon \Delta e}
$$

where

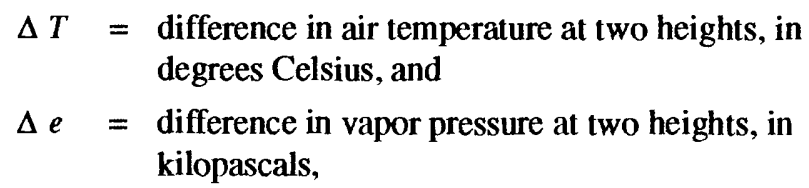

and other terms are as previously defined. Part of equation 10 , termed the psychrometric "constant", $\gamma$, is represented (Rosenberg and others, 1983, p. 255) by

$$
\gamma=\frac{P C_{p}}{L \varepsilon}
$$

where $\gamma$ is in kilopascals per degrees Celsius and other terms are as defined previously. This "constant" actually varies with altitude because of atmospheric pressure changes at different altitudes, and with temperature because of the dependence of $L$ on temperature.

By substituting $\gamma$ for $\frac{P C_{p}}{L \varepsilon}$, equation 10 can be fur-
ther simplified to

$$
\beta=\gamma \frac{\Delta T}{\Delta e}
$$

The psychrometric constant can be determined and the air temperature and vapor pressure differences can be measured to obtain the Bowen ratio. The energy budget can then be solved by rearranging equation 6 to

$$
H=\beta L E
$$

and then substituting equation 13 into equation 1 to yield

$$
L E=\frac{\left(R_{n}-G\right)}{(1+\beta)}
$$

ET can be calculated from the latent-heat flux, in watts per square meter, and converted to rate of water loss, in millimeters per day, by the equation 


$$
\mathrm{ET}=\left(\frac{L E}{L}\right)(86.4)
$$

The 86.4 is a factor derived from the conversion and reduction of units in the equation necessary to obtain ET in millimeters per day, as shown by Campbell (1977, p. 141).

The Bowen-ratio method works well under most conditions except when the ratio approaches -1 . When the Bowen ratio approaches -1, erroneous values of $L E$ can result because the denominator in equation 14 approaches zero. This condition commonly occurs at sunrise and sunset when the sensible-heat flux, $H$, is changing direction and is equal and opposite to the latent-heat flux, $L E$ (D.I. Stannard, U.S. Geological Survey, written commun., 1990). When

$$
|\beta+1|<\delta,
$$

where $\delta$ is some number less than 1 , the latent-heat flux must be calculated using an alternative method (D.I. Stannard, U.S. Geological Survey, written commun., 1990). In this study, $\delta$ was chosen to be 0.5 . Thus, Bowen ratios for the entire period of study that were between -0.5 and -1.5 were eliminated. These

Bowen-ratios were then replaced with averages of preceding and subsequent Bowen ratios with $\delta$ greater than 0.5. Because these periods are usually when all fluxes are near zero, estimates of $L E$ and $H$ made for these periods using this approach do not significantly change the daily calculations.

\section{Penman-Monteith Method}

The Penman-Monteith method, used to estimate actual ET, is a variation of the Penman method used to estimate potential ET. Both methods are combination methods combining energy-balance and aerodynamic principles. Potential ET is the maximum quantity of water loss from a vegetated surface when plants have unlimited water available. In semiarid areas, such as Snively Basin, actual ET is usually much less than potential ET. This condition occurs because soil water available to plants is limited and the potential rate of ET is seldom realized except during and shortly after heavy rain.
Penman (1948) was the first to introduce an evaporation equation for open water (Brutsaert, 1982, p. 215). Later, Penman (1956) described an equation to determine potential ET over any wet surface, where he made the assumption that the resistances to atmospheric heat and water-vapor diffusion were equal. This equation has been refined over the years (Tanner and Pelion, 1960; Van Bavel, 1966) and can be written (D.I. Stannard, U.S. Geological Survey, written commun., 1990) as

$$
L E_{p}=\left[\frac{s\left[R_{n}-G\right]+\left[\rho_{a} C_{p}\left(e_{s}-e\right)\right] / r_{h}}{s+\gamma}\right] \text {, }
$$

where

$$
\begin{aligned}
L E_{p}= & \begin{array}{l}
\text { potential evapotranspiration, in watts per square } \\
\text { meter, }
\end{array} \\
s \quad= & \begin{array}{l}
\text { slope of the saturation vapor-pressure curve at } \\
\text { air temperature, in kilopascals per degrees } \\
\end{array} \\
& \text { Celsius, } \\
\rho_{a}= & \begin{array}{l}
\text { density of air at site elevation, in grams per cubic } \\
\text { meter, }
\end{array} \\
e_{s}= & \begin{array}{l}
\text { saturation vapor pressure at air temperature, in } \\
\text { kilopascals, }
\end{array} \\
e \quad= & \text { vapor pressure of the air, in kilopascals, and } \\
r_{h}= & \text { aerodynamic resistance to heat flow, in seconds } \\
& \text { per meter, }
\end{aligned}
$$

and other terms are as previously defined.

The Penman equation can estimate potential ET accurately under conditions of unlimited water supply. However, because water is a limiting factor at the study site, actual ET estimates made with the Penman equation would be in error. This occurs because, as conditions become drier, for available water to be taken up by the plants roots and transpired through the leaves or evaporated from the soil, the water must overcome a resistance due to plant stomatal closure and partially dry soil; the Penman equation does not take this into account.

Variations of the Penman equation account for this resistance and enable actual ET to be calculated. One variation developed by Monteith (1963), termed the Penman-Monteith equation, includes a canopy resistance in the basic Penman equation, which then becomes 


$$
L E=\left[\frac{s\left[R_{n}-G\right]+\left[\rho_{a} C_{p}\left(e_{s}-e\right)\right] / r_{h}}{s+\gamma\left[\left(r_{c}+r_{h}\right) / r_{h}\right]}\right],
$$

where $r_{c}$ is the canopy resistance in seconds per meter, and other terms in the equation are as described previously. In practice, the canopy resistance is not measured directly, but is determined by computing the latent-heat flux for short periods by other means, such as the Bowen-ratio method, and then solving for $r_{c}$ in the Penman-Monteith equation. In this study, latent-heat fluxes calculated by the Bowen-ratio method were used to calculate $r_{c}$ in the Penman-Monteith equation.

When rearranged to solve for $r_{c}$, equation 17 becomes

$r_{c}=\frac{r_{h}}{\gamma}\left(\frac{1}{L E}\left[s\left(R_{n}-G\right)\left\{\frac{\rho_{a} C_{p} e_{s}-e}{r_{h}}\right\}\right]-s\right)-r_{h}$.

All terms are as previously defined.

In this study, the saturated vapor pressure, $e_{s}$, and vapor pressure, $e$, were determined from the measurements of relative humidity and air temperature. Saturated vapor pressure was calculated using an equation from Stull (1988, p. 276),

$$
e_{s}=0.6112 \exp \left[\frac{17.67(T-273.15)}{(T-29.66)}\right]
$$

where $T$ is the air temperature in Kelvin. When adjusted to use air temperature in degrees Celsius, the equation becomes

$$
e_{s}=0.6112 \exp \left[\frac{17.67 T}{(T+243.5)}\right]
$$

Using the relative-humidity measurement, vapor pressure can be calculated using the equation

$$
e=e_{s}\left(0.01 h_{r}\right) \text {, }
$$

where $h_{r}$ is the relative humidity in percent.

From equation 19 the slope of the saturation vapor-pressure curve is

$$
s=\frac{d}{d T}\left[0.6112 \exp \left[\frac{17.67(T-273.15)}{(T-29.66)}\right]\right]
$$

After mathematical derivation and conversion of $T$ to degrees Celsius, the equation becomes

$$
\begin{gathered}
s=0.6112\left[\left(\left[\frac{17.67}{(T+243.5)}\right]-\left[\frac{17.67 T}{(T+243.5)^{2}}\right]\right)\right. \\
\left.\exp \left[\frac{17.67 T}{(T+243.5)}\right]\right] .
\end{gathered}
$$

The aerodynamic resistance to heat, $r_{h}$, is the turbulent resistance between the leaf surfaces and the height of temperature and wind-speed measurements. Heat produced at the leaf surfaces must overcome this resistance to arrive at sensor height. For neutral atmospheric conditions, it is represented by Campbell $(1977$, p. 138) as

$$
r_{h}=\frac{\ln \left[\frac{\left(z-d+z_{h}\right)}{z_{h}}\right] \ln \left[\frac{\left(z-d+z_{m}\right)}{z_{m}}\right]}{k^{2} u},
$$

where

$z \quad=$ height of wind-speed measurement above the surface, in meters ( 3.0 meters in this study), 
$d=$ zero plane displacement height (distance from surface to mean height of heat, vapor, or momentum exchange), in meters,

$z_{h}=$ heat-transfer roughness length, in meters.

$z_{m}=$ momentum roughness length (related to the variance in canopy height), in meters,

$k=$ von Karman's constant, equal to 0.4, and

$u=$ wind speed at measurement height, $z$, in meters per second.

Some of the terms on the right-hand side of equation 24 are terms used in wind profile equations. The terms $d$, $z_{m}$, and $z_{h}$ are difficult to measure, but may be determined graphically from wind profiles or through empirical equations. For dense canopies, Campbell (1977, p. 38) suggests that $d$ equals 0.64 times the canopy height, $h$. Because the 0.35 meter canopy at the Snively Basin site is somewhat less than dense, a value for $d$ lower than 0.64 times $h$ seems reasonable because the level of heat, vapor, or momentum exchange will be closer to the surface than for a truly dense canopy. For this study, 0.50 times $h$ was chosen, giving a $d$ of 0.18 meter. The value chosen for $d$ does not have a major effect on the resulting value for $r_{h}$ in equation 24 because $d$ is much smaller than the $z$ of 3.0 meters (using a $d$ of zero changes the overall $r_{h}$ less than 2 percent from the $r_{h}$ obtained with a $d$ of 0.18 meter, other values being equal).

For this study, wind-speed data were obtained for a 2-week period at 1,2,3, and 4 meters above the canopy and several wind-speed profiles were plotted to estimate $z_{m}$ graphically. This method of determining $z_{m}$ works only for neutral conditions; the profiles used were chosen because they were log-linear, which reflects neutral atmospheric conditions. Using such profiles, the wind speeds were plotted on the $\mathrm{x}$-axis against the natural $\log$ of $z-d$ on the $y$-axis. Best-fit lines through the data were determined for each profile, and each line was extrapolated to $u=0$, where the value of the $y$-intercept was equal to the natural $\log$ of $z_{m}$. The average value of $z_{m}$ was 0.004 meter. This value seems reasonable based on tabled $z_{m}$ values for grasses of 0.001 meter to 0.0065 meter in Brutsaert (1982, p. 114). Campbell (1977, p. 39) relates that $z_{h}$ equals 0.2 times $z_{m}$, or 0.0008 meter for this study. When numerical values for the parameters $z, d, z_{m}, r_{h}$, and $k$ are inserted into equation 24 , it can be rewritten as

$r_{h}=\frac{\ln \left[\frac{(3.0-0.18-0.0008)}{0.0008}\right] \ln \left[\frac{(3.0-0.18-0.004)}{0.004}\right]}{0.16 u}$ and reduced to

$$
r_{h}=\frac{335}{u} .
$$

\section{PRELIMINARY EVALUATION OF EVAPOTRANSPIRATION}

A combination of the Bowen-ratio and Penman-Monteith methods was used to calculate ET for the entire period of study. Latent-heat fluxes (and ET) calculated with the Bowen-ratio method for periods with good-quality vapor-pressure data were used in the Penman-Monteith equation to estimate the canopy resistance. Canopy resistances for all available periods of each day were then averaged over the day; that average value of $r_{c}$ was used (with some exceptions) to recalculate the latent-heat flux (and ET) with the Penman-Monteith method. Methods of data analysis are presented; a sample calculation allows the reader to follow the procedures used step by step. Precipitation, ET estimates using Bowen-ratio and Penman-Monteith methods, and canopy resistances for the period of study are shown in table 1 .

\section{Calculations}

In this study, ET was calculated using a combination of the Bowen-ratio and Penman-Monteith methods. Data for Bowen-ratio calculations were collected at 20-minute intervals from May 30 to October 15. Data for Penman-Monteith calculations were collected at 60-minute intervals from May 30 to July 31 and at 20-minute intervals from August 1 to October 15. Latent-heat fluxes calculated for each 20-minute interval using the Bowen-ratio method were averaged over a 60-minute period (May 30 to July 31) or used directly (August 1 to October 15) in the Penman-Monteith equation to solve for the canopy resistance. Daily average canopy resistances were calculated and used in the Penman-Monteith equation to recalculate the latent-heat flux for each 20- to 60-minute period. Because there were gaps in the Bowen-ratio data (due to instrumentation error and adverse environmental conditions) and the Penman-Monteith data were complete, this approach allowed computation of latent-heat flux for the entire period of study.

A sample calculation of ET for the site for one 20-minute period is presented in the appendix at the end of this report. More detail on the steps used in this sample calculation follow. For the Bowen-ratio and 
Table 1.--Daily and monthly precipitation, evapotranspiration, and canopy resistances for Snively Basin site, May 31-October 15, 1990

[PRC, precipitation; BR, evapotranspiration, Bowen-ratio method; PM, evapotranspiration, Penman-Monteith method; RC, canopy resistance; TOT, monthly totals of daily precipitation and evapotranspiration; TR, data suggest trace of precipitation; *, estimated; $\mathrm{mm}$, millimeters; $\mathrm{s} / \mathrm{m}$, seconds per meter; --, insufficient data to calculate daily or monthly value; NA, not applicable]

\begin{tabular}{|c|c|c|c|c|c|c|c|c|c|c|c|c|}
\hline \multirow[b]{2}{*}{ Day } & \multicolumn{4}{|c|}{ May-June 1990} & \multicolumn{4}{|c|}{ July 1990} & \multicolumn{4}{|c|}{ August 1990} \\
\hline & $\begin{array}{l}\text { PRC } \\
(\mathrm{mm})\end{array}$ & $\begin{array}{l}\mathrm{BR} \\
(\mathrm{mm})\end{array}$ & $\begin{array}{l}\text { PM } \\
(\mathrm{mm})\end{array}$ & $\begin{array}{l}\mathrm{RC} \\
(\mathrm{s} / \mathrm{m})\end{array}$ & $\begin{array}{r}\text { PRC } \\
(\mathrm{mm})\end{array}$ & $\begin{array}{l}\text { BR } \\
(\mathrm{mm})\end{array}$ & $\begin{array}{l}\mathrm{PM} \\
(\mathrm{mm})\end{array}$ & $\begin{array}{l}\mathrm{RC} \\
(\mathrm{s} / \mathrm{m})\end{array}$ & $\begin{array}{l}\text { PRC } \\
(\mathrm{mm})\end{array}$ & $\begin{array}{l}\text { BR } \\
(\mathrm{mm})\end{array}$ & $\begin{array}{l}\text { PM } \\
(\mathrm{mm})\end{array}$ & $\begin{array}{l}\mathrm{RC} \\
(\mathrm{s} / \mathrm{m})\end{array}$ \\
\hline \multicolumn{13}{|l|}{ May } \\
\hline 31 & 0.51 & 0.97 & 1.05 & 540 & & & & & & & & \\
\hline \multicolumn{13}{|l|}{ June } \\
\hline 1 & .00 & 1.38 & 1.38 & 572 & 0.00 & 0.32 & 0.28 & 10,000 & 0.00 & 0.34 & 0.34 & 10,500 \\
\hline 2 & .00 & .76 & .79 & 1,670 & 1.52 & .36 & .36 & 5,910 & .00 & - - & .27 & 11,800 \\
\hline 3 & .00 & 1.99 & 2.28 & 210 & .00 & .30 & .24 & 10,800 & .00 & - & .24 & 13,100 \\
\hline 4 & .00 & 1.35 & 1.50 & 648 & .00 & .30 & .27 & 9,240 & .00 & - & .28 & 12,900 \\
\hline 5 & .00 & .98 & .83 & 1,480 & .00 & .24 & .16 & 13,700 & .00 & - & .34 & 12,800 \\
\hline 6 & 6.60 & 2.06 & 1.54 & 108 & .00 & .24 & .21 & 7,460 & .00 & - - & .36 & 11,200 \\
\hline 7 & .00 & 1.55 & 1.45 & 728 & .00 & .22 & .19 & 12,300 & .00 & - & .31 & 11,300 \\
\hline 8 & .00 & .73 & .93 & 831 & .00 & .32 & .32 & 9,590 & .00 & - & .17 & 23,000 \\
\hline 9 & .00 & .62 & .58 & 3,510 & .00 & .29 & .32 & 11,400 & .00 & - & .12 & 30,500 \\
\hline 10 & 1.27 & 1.69 & 1.86 & 413 & .00 & .65 & .61 & 5,540 & .00 & -- & .17 & 16,800 \\
\hline 11 & .00 & 1.15 & 1.25 & 608 & .00 & .37 & .36 & 13,000 & .00 & - - & .15 & 20,600 \\
\hline 12 & .00 & .75 & .73 & 1,040 & .00 & .33 & .32 & 14,200 & .00 & - & .19 & 19,900 \\
\hline 13 & .00 & .92 & .86 & 1,230 & .00 & .32 & .31 & 14,100 & .00 & - - & .18 & 18,900 \\
\hline 14 & .00 & 1.22 & 1.25 & 885 & .00 & .44 & .46 & 8,490 & .00 & -- & .17 & $16,900 *$ \\
\hline 15 & .00 & .93 & .97 & 1,870 & .00 & .37 & .30 & 14,300 & .00 & - & .12 & 15,000 \\
\hline 16 & .00 & .95 & 1.04 & 1,690 & .00 & .37 & .32 & 10,700 & .00 & - & .13 & $15,000 *$ \\
\hline 17 & .00 & .93 & .95 & 1,790 & .00 & .28 & .29 & 12,300 & TR & -- & .44 & 3,560 \\
\hline 18 & .00 & 1.01 & 1.04 & 1,730 & .00 & .26 & .27 & 12,600 & .00 & -- & .16 & 8,150 \\
\hline 19 & .51 & 1.51 & 1.63 & 1,250 & .00 & .40 & .45 & 7,620 & .TR & -- & .42 & 1,790 \\
\hline 20 & .00 & .80 & .65 & 2,550 & .00 & .29 & .32 & 11,500 & .00 & -- & .18 & 9,120 \\
\hline 21 & .00 & 1.13 & 1.09 & 2,160 & .00 & .38 & .37 & 10,000 & 28.19 & $1.56^{*}$ & 1.48 & $22.5^{*}$ \\
\hline 22 & .00 & .43 & .46 & 3,610 & .00 & .38 & .31 & 13,000 & .00 & - - & 1.98 & $427 *$ \\
\hline 23 & .00 & .96 & .84 & 2,980 & .00 & .40 & .45 & 5,620 & .00 & - - & 1.19 & $1,180 *$ \\
\hline 24 & .00 & .87 & .85 & 3,120 & TR & .55 & .59 & 2,380 & .00 & - - & .90 & $1,850 *$ \\
\hline 25 & .00 & .37 & .32 & 9,590 & 1.27 & .98 & 1.06 & 513 & .00 & - & .66 & $2,010 *$ \\
\hline 26 & .00 & .27 & .24 & 9,820 & .00 & .23 & .21 & 12,600 & .00 & - & .64 & $2,220 *$ \\
\hline 27 & .00 & .23 & .16 & 13,000 & .00 & .19 & .19 & 15,100 & .00 & - & .49 & $4,210 *$ \\
\hline 28 & .00 & .22 & .22 & 9,280 & .00 & .27 & .23 & 11,400 & .00 & $\cdots$ & .45 & $5,470 *$ \\
\hline 29 & .00 & .29 & .29 & 15,800 & .00 & .29 & .22 & 15,000 & 3.56 & - & .65 & $2,630 *$ \\
\hline 30 & .00 & .24 & .17 & 18,800 & .00 & .27 & .23 & 11,900 & .00 & - & 1.26 & $633 *$ \\
\hline 31 & & & & & .00 & .26 & .25 & 13,600 & .00 & - & .51 & $3,250 *$ \\
\hline TOT & .38 & 28.29 & 28.15 & NA & 2.79 & 10.87 & 10.47 & NA & 31.75 & - - & 14.95 & NA \\
\hline
\end{tabular}


Table 1.--Daily and monthly precipitation, evapotranspiration, and canopy resistances for Snively Basin site, May 31-October 15, 1990--Continued

\begin{tabular}{|c|c|c|c|c|c|c|c|c|}
\hline \multirow[b]{2}{*}{ Day } & \multicolumn{4}{|c|}{ September 1990} & \multicolumn{4}{|c|}{ October 1990} \\
\hline & $\begin{array}{l}\text { PRC } \\
(\mathrm{mm})\end{array}$ & $\begin{array}{l}\text { BR } \\
(\mathrm{mm})\end{array}$ & $\begin{array}{l}\mathrm{PM} \\
(\mathrm{mm}\end{array}$ & $\begin{array}{l}\mathrm{RC} \\
(\mathrm{s} / \mathrm{m})\end{array}$ & $\begin{array}{r}\text { PRC } \\
(\mathrm{mm})\end{array}$ & $\begin{array}{l}\text { BR } \\
(\mathrm{mm})\end{array}$ & $\begin{array}{l}\text { PM } \\
(\mathrm{mm})\end{array}$ & $\begin{array}{l}\mathrm{RC} \\
(\mathrm{s} / \mathrm{m})\end{array}$ \\
\hline 1 & .00 & - & 0.37 & $5,860 *$ & 0.00 & - & 0.04 & $23,500^{*}$ \\
\hline 2 & .00 & - & .35 & $6,390 *$ & .00 & - - & .03 & 23,100 \\
\hline 3 & .00 & $\cdots$ & .21 & $8,760 *$ & .00 & - & .03 & $29,200 *$ \\
\hline 4 & .00 & - & .24 & $10,700 *$ & .00 & - & .02 & 35,400 \\
\hline 5 & .00 & $\cdots$ & .28 & $10,600 *$ & .00 & - - & .02 & $38,100 *$ \\
\hline 6 & .00 & - & .28 & $10,000 *$ & .00 & - & .02 & 41,000 \\
\hline 7 & .00 & - & .15 & 11,700 & .00 & - & .02 & $41,000 *$ \\
\hline 8 & .00 & - & .23 & 12,200 & .00 & - & .02 & $41,000 *$ \\
\hline 9 & .00 & - & .22 & 12,500 & .00 & - & .02 & 41,500 \\
\hline 10 & .00 & -- & .20 & 14,200 & .00 & -- & .02 & $41,600 *$ \\
\hline 11 & .00 & - & .24 & 12,500 & .00 & $\ldots$ & .02 & 41,700 \\
\hline 12 & .00 & - & .16 & $12,000 *$ & .00 & - & .02 & 42,300 \\
\hline 13 & .00 & $\cdots$ & .14 & $12,000^{*}$ & .00 & - & .01 & $42,000 *$ \\
\hline 14 & .00 & -- & .18 & $12,000 *$ & 2.29 & 1.18 & .89 & 71.8 \\
\hline 15 & .00 & $\ldots$ & .10 & 11,800 & .00 & - - & .65 & 629 \\
\hline 16 & .00 & - & .11 & $12,000 *$ & & & & \\
\hline 17 & .00 & -- & .14 & $12,000 *$ & & & & \\
\hline 18 & .00 & $\ldots$ & .14 & $12,000 *$ & & & & \\
\hline 19 & .00 & $\ldots$ & .15 & $12,000 *$ & & & & \\
\hline 20 & .00 & - & .13 & $12,000 *$ & & & & \\
\hline 21 & .00 & -. & .17 & $12,000 *$ & & & & \\
\hline 22 & .00 & $\cdots$ & .17 & 11,300 & & & & \\
\hline 23 & .00 & -- & .14 & 17,100 & & & & \\
\hline 24 & .00 & - & .14 & 18,900 & & & & \\
\hline 25 & .00 & - - & .10 & 20,700 & & & & \\
\hline 26 & .00 & - - & .14 & 13,700 & & & & \\
\hline 27 & .00 & - & .10 & 19,100 & & & & \\
\hline 28 & .00 & - & .13 & 15,000 & & & & \\
\hline 29 & .00 & - & .12 & 19,500 & & & & \\
\hline 30 & .00 & - & .07 & 24,000 & & & & \\
\hline TOT & 0.00 & - & 5.30 & NA & 2.29 & $\cdots$ & 1.83 & NA \\
\hline
\end{tabular}


Penman-Monteith methods, the latent heat of vaporization of water, $L$, and the psychrometric constant, $\gamma$, are determined using equations 3 and 11 , respectively (steps 1 and 2). To compute the Bowen ratio, air temperature and vapor pressure data collected at two heights are used with the calculated psychrometric constant in equation 12 (step 3). Soil-heat flux, $G$, is calculated by using equation 4 to find the soil-heat-storage component (step 4) and adding the result to the average of two soil-heat flux plates as shown in equation 5 (step 5). Using field-collected net radiation data with calculated soil-heat flux and Bowen-ratio values, the latent-heat flux, $L E$, can be determined using equation 14 (step 6). The sensible-heat flux, $H$, is determined using equation 13 (step 7) and the rate of ET (Bowen-ratio method) can then be found by using equation 15 (step 8). All these calculations were performed for each 20-minute or 60-minute interval of collected data. Identical net-radiation, $R_{n}$, and soil-heat flux, $G$, values were used in Bowen-ratio and Penman-Monteith calculations of $L E$ and $H$.

The Penman-Monteith equation was then used to calculate the canopy resistance. Calculated inputs to the Penman-Monteith equation include the slope of the saturated vapor-pressure curve, values of vapor pressure and saturated vapor-pressure, the psychrometric constant, the aerodynamic resistance to heat, and the canopy resistance. The slope of the saturated vapor-pressure curve was computed using air temperature in equation 23 (step 9). Saturated vapor pressure was determined by equation 20 (step 10). The actual vapor pressure was then determined with equation 21 using the calculated saturated vapor-pressure values and relative-humidity data (step 11). The aerodynamic resistance to heat, $r_{h}$, was determined with equation 25 (step 12).

The canopy resistance, $r_{c}$, was found by using latent-heat flux values determined by the Bowen-ratio method in equation 18 (step 13). These values were then used to calculate an average canopy resistance for each day, as discussed in the section "canopy-resistance estimates". These average values (shown in table 1) were used to recalculate the latent-heat flux for each period using the Penman-Monteith method. The recalculated latent-heat fluxes using the Penman-Monteith method were found by substituting calculated values, collected data, and computed variables, including the canopy resistance from table 1, into equation 17 (step 14). Rates of $E T$ (Penman-Monteith method) were then calculated using equation 15 (step 15).

\section{Energy-Balance Fluxes}

In an energy balance, net radiation is the primary flux driving the other fluxes (soil-heat flux, sensible-heat flux, and latent-heat flux) and is normally the largest component. Energy-balance plots for three 5-day periods (figure 4) show these fluxes. Latent and sensible-heat fluxes were calculated with the Penman-Monteith method. Net-radiation curves on clear days are very smooth (see June 21 on figure 4). Clouds passing over the site (see June 20 on figure 4) cause irregularities in the net-radiation curves, and these irregularities are also usually reflected in the other fluxes.

During days of precipitation (June 6 on figure 4 for example), net radiation produced little surface warming and soil and sensible-heat fluxes remained low. Most of the heat generated by net radiation was lost through ET and the latent-heat flux approached the net radiation value.

Energy-balance plots for periods where the top layer of soil and the air were very dry (July 14-18 on figure 4, for example) show that most of the heating created by net radiation became sensible-heat flux and, to a lesser extent, soil-heat flux. In this case, sensible-heat flux approached the net radiation value while the latent-heat flux approached zero.

Errors in measurement of net radiation and soil-heat flux affect the calculation of latent-heat-flux and ET. These errors are probably small, however. Net radiation values, as measured by two net radiometers, agreed within 5 percent, and soil-heat-flux values, which were usually less than 10 percent of the energy budget at the study site, generally agreed within 20 percent.

\section{Canopy-Resistance Estimates}

The canopy resistances used with the PenmanMonteith method were daily averages of canopy resistance calculated with Bowen-ratio latent-heat fluxes for each time interval, when those fluxes could be calculated. From May 30 to July 31, when the Bowen-ratio latent-heat flux values were calculated at 20-minute intervals and the Penman-Monteith data were at 60-minute intervals, 60-minute averages for the Bowen-ratio latent-heat fluxes were calculated and used in the Penman-Monteith equation. Canopy resistances were computed for daytime periods from about 8 a.m.to 5 p.m., when ET was highest. 

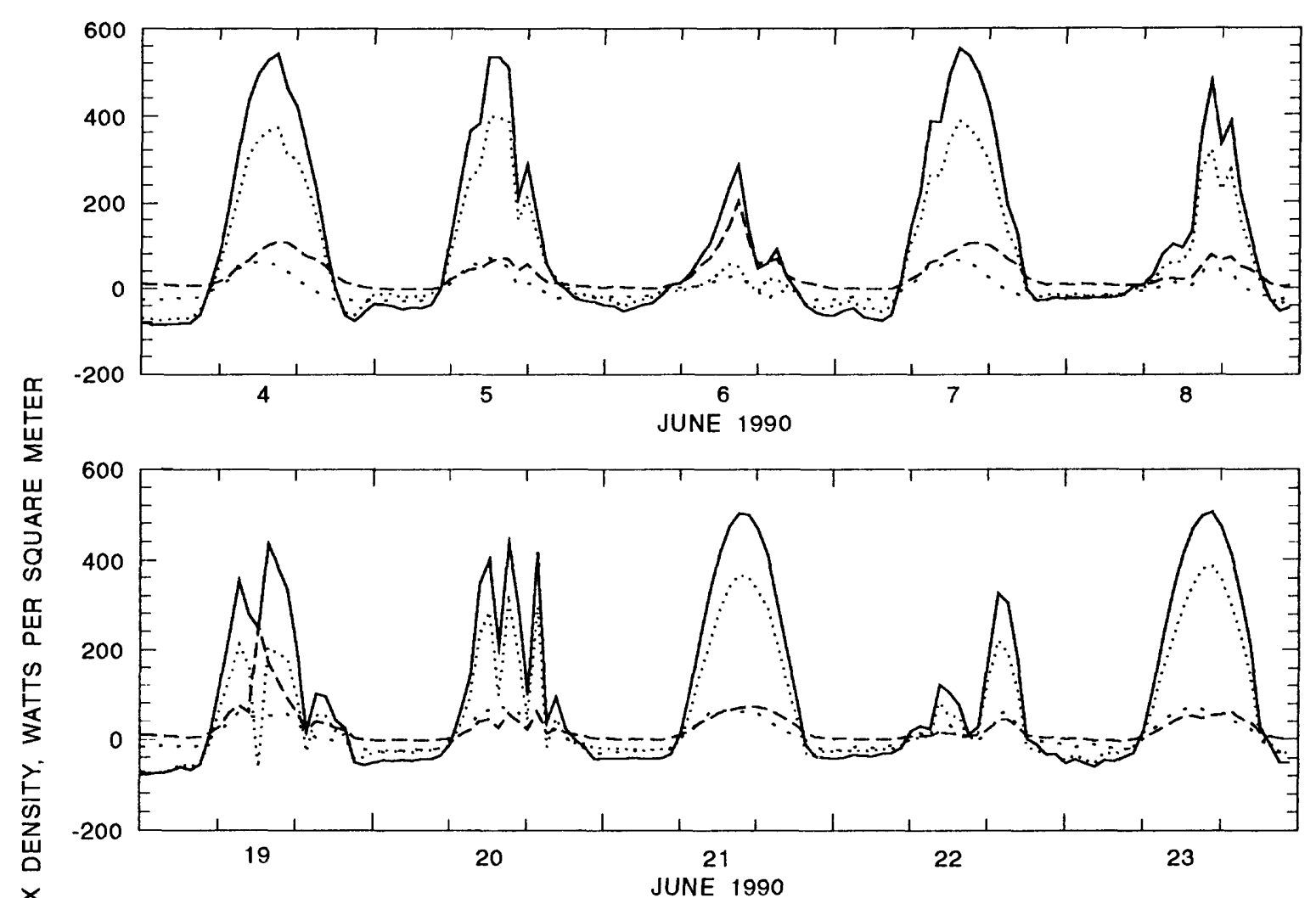

$\stackrel{\times}{\vec{u}}$

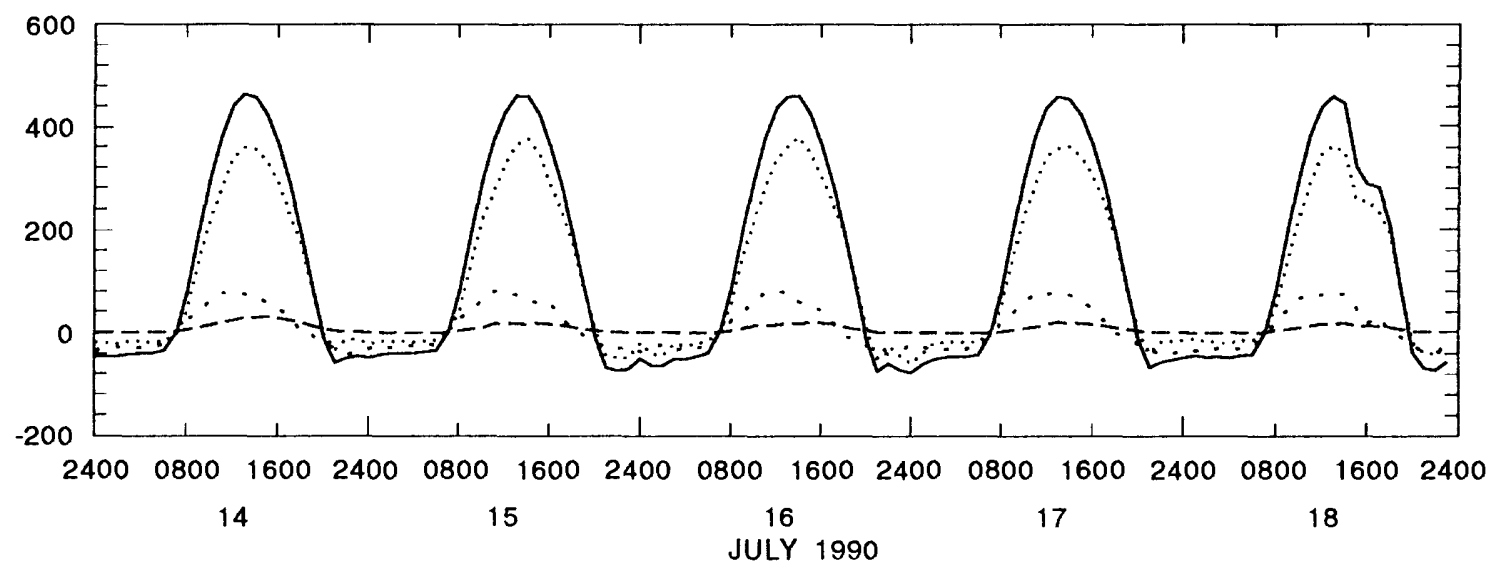

EXPLANATION

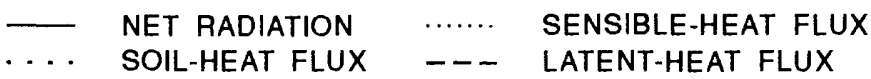

Figure 4.--Energy balance for Snively Basin evapotranspiration site. 
Vapor-pressure and air temperature difference data needed to calculate latent-heat fluxes with the Bowen-ratio method were discontinuous because of sensor problems or adverse environmental conditions. The latent-heat fluxes that were calculated with the intermittent Bowen-ratio data were used to calibrate the Penman-Monteith equation for the canopy resistance. This provided a set of canopy resistances for a number of time periods each day. These canopy resistances were averaged. Then, the latent-heat flux was recalculated using the Penman-Monteith method with the average daily canopy resistance, for every time interval of that day. Because the data needed to compute ET with the Penman-Monteith method were complete for all time intervals in the period of study, this approach allowed ET to be calculated for every day of the study period.

Generally, the daily average canopy resistance was used for all Penman-Monteith calculations for that day. The next two paragraphs outline exceptions to this procedure.

Where Bowen-ratio latent-heat-flux calculations were considered inaccurate, or could not be calculated because of missing data for an entire day or days, canopy resistances were either estimated or interpolated from canopy resistances calculated on adjacent days. The canopy resistances for these estimated days are based on environmental conditions known from available data. However, considering the variability of the canopy resistance during known periods, it is possible the true resistances are as much as 100 percent different from the estimated values, which would affect the daily ET rate by almost as much. Fortunately, most of these periods are when ET is near zero, so their cumulative affect on monthly or seasonal ET is small. For instance, doubling the calculated ET for all of September only increases the ET for the study period by 8.7 percent.

The accuracy of the Penman-Monteith calculations was increased by accounting for changing environmental conditions, such as developing or lapsing rain. For example, when rain fell for only part of a day, the $r_{c}$ value for the intervals when it was raining was different from the one used in the time intervals where it was not. The changes in $r_{c}$ during rainy periods were incorporated in the calculations because they can be very large, as much as 1,000 percent or more from non-rainy periods in the same day. Using a straight daily average $r_{c}$ for days with rain would erroneously produce high values of latent-heat flux and ET. This results from the daily average $r_{c}$ being skewed by low values of $r_{c}$ occurring during the short periods of rain.
The methods used to estimate canopy resistance may include errors in calculation of other variables, such as $r_{h}$. For example, during non-neutral conditions, the equation used to calculate $r_{h}$ can sometimes overestimate that term by as much as a factor of 2 (D.I. Stannard, U.S. Geological Survey, written commun., 1992), which in turn tends to overestimate $r_{c}$. To a degree, the errors produced tend to cancel out and little effect is noticed on resultant values of ET. The averaging of the 20 and 60 -minute interval canopy resistances also may introduce some error since the canopy resistance varied as much as 100 percent or more from one 20 or 60 -minute period to another. This is the result of changing environmental conditions or instrument error.

Averaging the canopy resistances, however, generally produced a small overall daily effect on latent-heat flux calculations. Latent-heat flux values for three 5-day periods calculated with the Bowen-ratio method and with the Penman-Monteith method are shown on figure 5. These periods represent most of the conditions seen over the period of study. On days without precipitation, such as June $14-18$, 1990, and July 26-28, 1990, on fig. 5, canopy resistances are nearly constant during the course of the day, providing good agreement between Bowen-ratio and Penman-Monteith calculated latent-heat fluxes.

On days of heavy precipitation, June 6 (fig. 5) for example, the Bowen-ratio latent-heat flux is higher than the Penman-Monteith calculated latent-heat flux. This is due, in part, because the Bowen-ratio calculated latent-heat flux is sometimes slightly higher than the net radiation. When calibrating the Penman-Monteith equation for the canopy resistance with these latent-heat fluxes, negative resistances result. Because resistances cannot be negative, zero values are used for the canopy resistance in the Penman-Monteith equation during these periods. The net result is a 25-percent underestimation of latent-heat flux with the Penman-Monteith method. However, this is the worst case example under such conditions for the period of study. During other rainy days, such as July 25 (fig. 5), latent-heat fluxes calculated with the two methods average less than 10 percent different from one another.

On some days, June 5 and July 24 (fig. 5) for example, canopy resistances varied as much as 100 percent during the course of the day as drying and stomatal closure occurred, and latent-heat fluxes calculated with the two methods do not agree well. On a daily basis, however, these differences appear to average out. This extreme variance of the canopy resistance is unusual in the period 

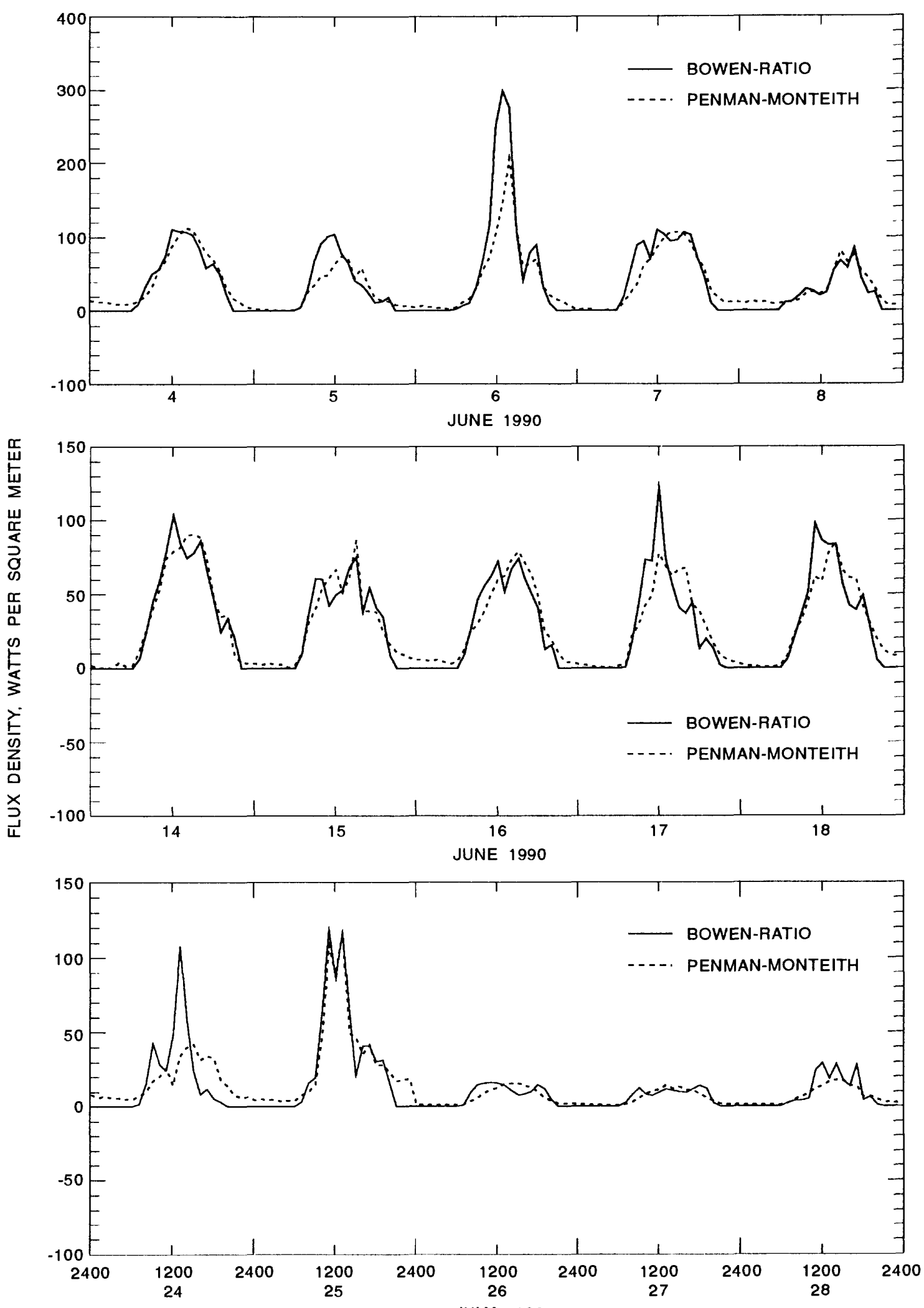

JULY 1990

Figure 5.--Comparison of Bowen-ratio and Penman-Monteith latent-heat fluxes for Snively Basin evapotranspiration site. 
of study for which there are complete data. Also, by varying $r_{c}$ during periods of rain, better agreement with Bowen-ratio latent-heat fluxes was obtained.

The canopy-resistance $r_{c}$, was used as an overall calibration factor between the Bowen-ratio and PenmanMonteith methods of determining ET. Average daily values of $r_{c}$ used in the Penman-Monteith calculations are presented in table 1 , along with daily precipitation and evapotranspiration.

Canopy-resistance values in table 1 varied widely. Under very moist conditions, such as rain, the $r_{c}$ values were near zero. When conditions were extremely dry, as in early August, September, and early October, and latent-heat fluxes were near zero, $r_{c}$ ranged from 20,000 to 40,000 seconds per meter. Typically, the canopy resistance would decrease dramatically with precipitation, then gradually rise as environmental conditions became drier. An example of this occurred June 6 to June 9 (table 1).

\section{Evapotranspiration Estimates}

ET from growing plants at the site begins in mid to late March as temperatures rise, daylight increases, and vegetation greens, and continues through April and May. Because data collection began on May 30,1990, much of the ET for the 1990 growing season was missed. Daily amounts of ET and precipitation for May 31 to

October 15, 1990, were calculated and are listed in table 1. Daily amounts of ET in table 1 reflect the average of 60-minute or 20-minute incremental ET rates for a day. The daily amount of ET is, effectively, the mean daily ET rate times one day. Therefore, daily amounts of ET and mean daily ET rates are numerically equivalent. Daily amounts of ET calculated with the Bowen-ratio and Penman-Monteith methods are graphically presented on figure 6.

ET amounts for the period of study varied considerably. Daily ET from May 31 to June 24 generally ranged from 1 to 2 millimeters as vegetation thrived and top-layer soil moisture decreased from 9.0 to 4.0 percent. From June 25 to July 25 , daily ET averaged 0.4 millimeter, ranging from 0.2 to 1 millimeter; vegetation at the site began to dry and turn brown as soil moisture decreased from 4.0 to 3.0 percent. As summer progressed from July 26 to August 20, daily ET of 0.4 millimeter or less was common and soil moisture decreased from 3.0 to 2.4 percent. During or shortly after days of rain, daily ET increased, sometimes dramatically (see table 1 and figure 6 ) if the rainfall was large, then gradually decreased. During the extremely dry periods, when the daily ET and latent-heat fluxes were near zero, almost all energy moved up through the canopy layer as sensible-heat flux. The perennial bluebunch wheatgrass became dormant and annual cheatgrass and Sandberg's bluegrass seeded and perished during these periods.

On August 21, a series of thunderstorms produced 28.19 millimeters of rainfall at the site. Near-surface soil moisture increased from 2.4 to approximately 14 percent. Daily ET increased to more than 1 millimeter for three days, then dropped until August 29, when a light rainfall again raised the daily ET over 1 millimeter. Daily ET then continued dropping, and by September 2, it was about 0.3 millimeter per day. Most of the ET from August 21 to September 2 was probably soil evaporation, because the vegetation had perished or become dormant for the season; top-layer soil moisture during this period decreased from 14 to 7.5 percent. Seedling growth as a result of the rainfall was evident on September 6. Storms of the magnitude that occurred on August 21 are uncommon in the area. Hanford, the nearest long-term meteorological station, averages only two thunderstorms during August and the average number of days with 25 millimeters or more of precipitation is near zero (Stone and others, 1983). Total precipitation at Hanford in August averages 6 millimeters, and for Snively Basin about 12 millimeters.

From September 3 to October 13, conditions became very dry as soil moisture decreased from 7.5 to

3.5 percent, and daily ET amounts were less than 0.3 millimeter. No rainfall occurred at the site until mid-October. On October 14, 2.29 millimeters of rainfall occurred and daily ET increased to about 1 millimeter. On October 15, the cooled-mirror hygrometer was dismantled and removed from the site because of its sensitivity to freezing; therefore, no further data for calculating ET with the Bowen-ratio method were collected in 1990.

On the basis of the daily ET amounts shown in table 1, the monthly totals for ET are as follows: June, 28.2 millimeters; July, 10.5 millimeters; August, 15.0 millimeters (68 percent of that occurring after the August 21 thunderstorms); September, 5.3 millimeters; and October 1-15, 1.8 millimeters.

The ET values presented in this report (table. 1) are estimates. The methods used for data collection, data analysis, and ET calculation likely introduce some error into these estimates, primarily through the canopy-resistance term in the Penman-Monteith equation. Some of these errors may be very large on a daily basis when ET is near zero, but their cumulative effect is expected to be 


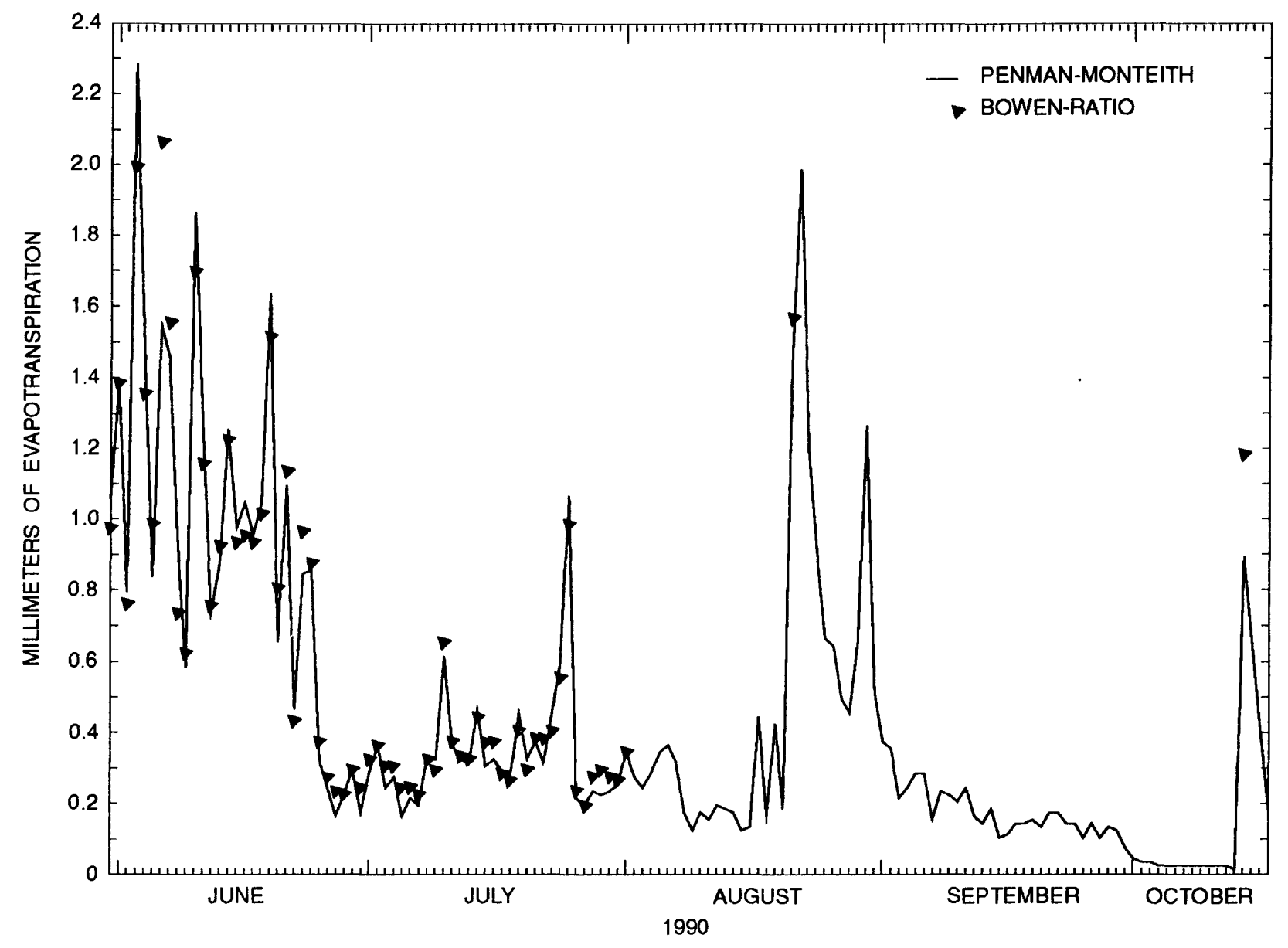

Figure 6.--Daily Bowen-ratio and Penman-Monteith evapotranspiration for Snively Basin site, May 31-October 15, 1990.

small on the basis of results from the first part of the study period. During June and July 1990, when Bowen-ratio and Penman-Monteith ET estimates were made for all days, daily ET calculated with the Penman-Monteith method varied with ET calculated with the Bowen-ratio method by a maximum of about 25 percent. On a monthly total basis, Penman-Monteith calculated ET varied with Bowen-ratio calculated ET less than 1 percent in June and 4 percent in July. The variabilities in the two methods for August, September, and early October would probably be higher because of the estimation of the canopy resistance using incomplete Bowen-ratio vapor-pressure data.

However, these variabilities cannot be quantified for this period since daily Bowen-ratio ET estimates could not be made on most days.

Field data and calculated energy-balance fluxes are too voluminous to publish. They are available from the U.S. Geological Survey, Water Resources Division office in Tacoma, Wash., upon request in ASCII (American Standard Code for Information Interchange) format on floppy diskettes. The field data are contained on five 1.2 megabyte diskettes. The calculated energy-balance fluxes and intermediate computations are included on ten 1.2 megabyte diskettes.

\section{SUMMARY}

Evapotranspiration (ET) was estimated using the Bowen-ratio and Penman-Monteith methods for a grassland site in Snively Basin of the Arid Lands Ecology Reserve on the Hanford Nuclear Reservation, Washington, for the period May 30 to October 15, 1990. Both methods involve an energy-balance approach often used to calculate ET. This approach conceptualizes a layer between the soil surface and an imaginary surface just above the vegetative canopy. Net radiation, soil-heat flux, sensible-heat 
flux, and latent-heat flux are the energy-balance components crossing this layer. Latent-heat fluxes calculated with the Bowen-ratio method were used to calibrate the Penman-Monteith equation for the canopy resistance. Energy-balance fluxes and rates of evapotranspiration were then calculated using the Penman-Monteith method.

For the Bowen-ratio approach, data for net radiation, soil temperature, soil-heat flux, soil-moisture content, and air temperature and vapor pressure at two heights were collected. These data were input to the Bowen-ratio and energy-balance equations for each 20-minute period to determine latent-heat flux, sensible-heat flux, and soil-heat flux. Owing to instrument malfunctions and occasional adverse weather conditions, a continuous record of latent-heat fluxes and ET could not be calculated with the Bowen-ratio nethod.

Variables measured or estimated for the PenmanMonteith method included net radiation, air temperature, relative humidity, wind speed, soil temperature, and soil-heat flux and values for aerodynamic resistance to heat and canopy resistance. Solar radiation, precipitation, and soil-moisture data also were collected. Wind-speed profile data were collected and analyzed to calculate the momentum roughness length needed to estimate the aerodynamic resistance to heat for the Penman-Monteith method.

The canopy resistance was estimated as follows. Daytime latent-heat flux values calculated with the Bowen-ratio method were input to the Penman-Monteith equation to solve for the resistance. Resultant canopy-resistance values were averaged for each day of the study period. For days where no Bowen-ratio calculated latent-heat fluxes were available, the canopy resistance was interpolated from previous and subsequent daily resistances, or estimated through consideration of site conditions. The canopy resistance was variable over the period of study, ranging from near zero during periods of rainfall to more than 40,000 seconds per meter during periods of extreme dryness.

The daily canopy-resistance values were used with the value for aerodynamic resistance to heat, several site-specific variables, and collected data to calculate latent-heat flux with the Penman-Monteith equation for the entire period of study. Values for sensible-heat flux and soil-heat flux were calculated using the energy-budget equation, and time-series plots of the computed fluxes and net radiation were prepared.
Using latent-heat fluxes computed with the Penman-Monteith methods, rates of ET were calculated for the entire period of study. Mean and maximum ET rates were converted to daily quantities for each day and tabulated. Daily ET ranged from less than 0.1 millimeter on several days in September and October to

2.3 millimeters on June 3. Monthly totals of ET also were calculated. These totals ranged from 5.3 millimeters in September to 28.2 millimeters in June.

The values of ET presented are estimates. Complexities of data collection, data analysis, and canopy-resistance estimation for the Penman-Monteith method likely introduce some error into these estimates, particularly when daily ET was near zero in August, September, and October. During June and July, however, Bowen-ratio and Penman-Monteith calculated ET agreed within about 25 percent on a daily basis and within 4 percent on a monthly basis. Variabilities between daily and monthly total ET estimates made with the two methods in August, September, and October would likely be higher. However, these cannot be quantified because poor-quality vapor pressure data collected during this period did not allow ET estimates to be made on most days with the Bowen-ratio method.

\section{REFERENCES CITED}

Bauer, H.H. and Vaccaro, J.J., 1990, Estimates of ground-water recharge to the Columbia Plateau Regional Aquifer System, Washington, Oregon, and Idaho, for predevelopment and current land-use conditions: U.S. Geological Survey Water-Resources Investigations Report 88-4108, $37 \mathrm{p}$.

Bowen, I.S., 1926, The ratio of heat losses by conduction and by evaporation from any water surface: Physical Review, v. 27, p. 779-787.

Brutsaert, W., 1982, Evaporation into the atmosphere: Dordrecht, D. Reidel, 299 p.

Campbell, G.S., 1977, An introduction to environmental biophysics: New York, Springer-Verlag, 159 p.

Campbell Scientific, Inc.. 1991, CSI Bowen-ratio instrumentation instruction manual, Logan, 30 p., in 4 sections.

Franklin, J.F., and Dyrness, C.T., 1988, Natural vegetation of Oregon and Washington: Corvallis, Oregon State University Press, 452 p. 
Gee, G.W., and Heller, P.R., 1985, Unsaturated water flow at the Hanford site: A review of literature and annotated bibliography: Pacific Northwest Laboratory Report PNL-5248, UC-70, 42 p.

Gee, G.W., and Hillel, D., 1988, Groundwater recharge in arid regions: Review and critique of estimation methods: Hydrological Processes, v. 2, p. 255-266.

Gee, G.W., and Jones, T.L., 1985, Lysimeters at the Hanford site: Present use and future needs: Pacific Northwest Laboratory Report PNL-5578, UC-70, 33 p.

Gee., G.W., and Kirkham, R.R., 1984, Arid site water balance: Evapotranspiration modeling and measurements: Pacific Northwest Laboratory Report PNL-5177, UC-70, 38 p.

Graham, M.J., 1981, Hydrology of the separations area: Rockwell International, Rockwell Hanford Operations, Energy Systems Group, Report RHO-ST-42, p. 1-1 to 1-3.

Haan, C.T., Johnson, H.P., and Brakensiek, D.L., 1982, Hydrologic modeling of small watersheds: American Society of Agricultural Engineers Monograph No. 5, $533 \mathrm{p}$.

Hajek, B.F., 1966, Soil survey, Hanford Project in Benton County, Washington: Pacific Northwest Laboratory, Richland, Washington, Report no. BNWL-243, UC-51, 16 p.

Harr, R.D., and Price, K.R., 1972, Evapotranspiration from a greaswood-cheatgrass community: Water Resources Research, v. 8, no. 5, p. 1199-1203.

Hayes, D.W., and Garrison, G.A., 1960, Key to important woody plants of eastern Oregon and Washington: U.S. Department of Agriculture, Handbook No. 148, U.S. Government Printing Office, 227 p.

Link, S.O., Gee, G.W., Thiede, M.E., and Beedlow, P.A., 1990, Response of a shrub-steppe ecosystem to fire: Soil water and vegetational change: Arid Soil Research and Rehabilitation, v. 4, p. 163-172.
Monteith, J.L., 1963, Gas exchange in plant communities, Environmental Control of Plant Growth (L.T. Evans, ed): New York, Academic Press, p. 205-234.

Penman, H.L., 1948, Natural evaporation from open water, bare soil and grass: Proceedings of the Royal Society of London, Series A, v. 193, p. 120-145.

Penman, H.L., 1956, Estimating evaporation: American Geophysical Union Transactions, v. 37, no. 1, p. 43-50.

Rockwell International, 1979, Compilation geologic map of the Pasco basin, south-central Washington: Rockwell Hanford Operations, Energy Systems Group, Richland, Washington, Sheet 12.

Rosenberg, N.J., Blad, B.L., and Verma, S.B., 1983, Microclimate: The biological environment: New York, John Wiley and Sons, 495 p.

Ruffner, J.A., and Bair, F.E., 1987, Weather of U.S. cities (3d ed.), v. 2, city reports, Montana-Wyoming: Gale Research Co., 1131 p.

Schwab, G.E., Colpitts, R.M., Jr., and Schwab, D.A., 1979, Spring inventory of the Rattlesnake Hills: W.K. Summers and Associates, Inc., $186 \mathrm{p}$.

Stone, W.A., Thorp, J.M., Gifford, O.P., and Hoitink, D.J., 1983, Climatological summary for the Hanford area: Pacific Northwest Laboratory Report PNL-4622, UC-11, Appendix V, p. 1-11.

Stull, R.B., 1988, An introduction to boundary layer meteorology: Dordrecht, Kluwer Academic Publishers, 666 p.

Tanner, B.D., 1988, Use requirements for Bowen ratio and eddy correlation determination of evapotranspiration: Proceedings of the 1988 special conference of the Irrigation and Drainage Division, Lincoln, Nebraska: American Society of Civil Engineers, 12 p.

Tanner, B.D., Greene, J.P., and Bingham, G.E., 1987, A Bowen ratio design for long term measurements: American Society of Agricultural Engineers, Paper no. $87-2503,12 \mathrm{p}$. 
Tanner, C.B., and Pelton, W.L., 1960, Potential evapotranspiration estimates by the approximate energy balance method of Penman: Journal of Geophysical Research, v. 65, no. 10, p. 3391-3413. 
APPENDIX 
The following are sample data set and step-by-step calculation of evapotranspiration using Bowen-ratio and Penman-Monteith methods. For August 19,1990, at 3:20 p.m., the following data were collected at the site:

Difference between upper and lower thermocouples:

$\Delta T=0.296^{\circ} \mathrm{C}$

Lower vapor pressure: $e_{1}=1.450 \mathrm{kPa}$.

Upper vapor pressure: $e_{2}=1.443 \mathrm{kPa}$.

Difference in soil-temperature readings: $\Delta T_{s}=0.036^{\circ} \mathrm{C}$.

Soil-heat-flux plate 1: $F X 1=7.15 \frac{\mathrm{W}}{\mathrm{m}^{2}}$.

Soil-heat-flux plate 2: $\quad F X 2=8.66 \frac{W}{m^{2}}$.

Net radiation: $R_{n}=113.4 \frac{W}{m^{2}}$.

Temperature relative-humidity probe temperature:

$T=20.74^{\circ} \mathrm{C}$

Relative humidity: $h_{r}=65.35$ percent.

Wind speed: $u=1.393 \frac{\mathrm{m}}{\mathrm{s}}$.

The following values are also needed in the evapotranspiration calculations:

Atmospheric pressure at site: $P=95.66 \mathrm{kPa}$.

Specific heat of air: $C_{p}=1.005 \frac{J}{g^{\circ} C}$.

Ratio of molecular weight of water to air: $\varepsilon=0.622$.

Time difference between measurements:

$\Delta t=20$ minutes $=1,200$ seconds .

Depth to soil-heat flux plates: $d=0.05 \mathrm{~m}$.

Soil bulk density: $\rho_{b}=1,516 \frac{\mathrm{kg}}{\mathrm{m}^{3}}$.
Specific heat of dry soil: $C_{s}=837 \frac{\left(\frac{J}{k g}\right)}{{ }^{\circ} \mathrm{C}}$.

Soil water content: $W=0.024 \frac{\mathrm{kg} \mathrm{H}_{2} \mathrm{O}}{\mathrm{kg} \mathrm{soil}}$.

Specific heat of water: $C_{w}=4,190 \frac{\left(\frac{J}{k g}\right)}{{ }^{\circ} \mathrm{C}}$.

Site air density (based on sea-level pressure at $20^{\circ} \mathrm{C}$ ):

$\rho_{a}=1,137 \frac{g}{m^{3}}$.

The following steps show how the data are manipulated to calculate energy-balance fluxes and rate of evapotranspiration with the Bowen-ratio and Penman-Monteith methods.

Step 1: Calculate latent-heat of vaporization, $L$, using equation 3.

$L=2,502.3-2.308 T$

$L=2,502.3-2.308(20.74)=2,454 \frac{J}{g}$

Step 2: Calculate the psychrometric constant, $\gamma$, using equation 11.

$\gamma=\frac{P C_{p}}{L \varepsilon}$

$$
\gamma=\frac{(95.66)(1.005)}{(2,454)(0.622)}=0.0630 \frac{k P a}{{ }^{\circ} \mathrm{C}}
$$


Step 3: Calculate the Bowen ratio, $\beta$, using equation 12, given that $\Delta e=e_{1}-e_{2}$.

$\beta=\gamma \frac{\Delta T}{\Delta e}$

$\beta=(0.0630) \frac{(0.296)}{(1.450-1.443)}=2.66$

Step 4: Calculate soil-heat storage, $S$, using equation 4.

$$
\begin{aligned}
S & =\left(\frac{\Delta T_{s}}{\Delta t}\right) d \rho_{b}\left[C_{s}+\left(W C_{w}\right)\right] \\
S & =\left(\frac{0.036}{1,200}\right)(0.050)(1,516)[837 \\
& +(0.024)(4,190)]=2.13 \frac{W}{m^{2}}
\end{aligned}
$$

Step 5: Calculate the soil-heat flux, G, using equation 5.

$$
G=\left(\frac{F X 1+F X 2}{2}\right)+S
$$

$G=\left(\frac{(7.15+8.66)}{2}\right)+2.13=10.0 \frac{W}{m^{2}}$

Step 6: Calculate latent-heat flux, $L E$, using equation 14.

$L E=\frac{\left(R_{n}-G\right)}{(1+\beta)}$

$L E=\frac{(113.4-10.0)}{(1+2.66)}=28.3 \frac{W}{m^{2}}$
Step 7: Calculate the sensible-heat flux, $\mathrm{H}$, using equation 13.

$$
H=\beta L E=(2.66)(28.3)=75.3 \frac{W}{m^{2}}
$$

Step 8: Calculate the rate of evapotranspiration (Bowen-ratio method) using equation 15.

$$
\begin{aligned}
& E T=\left(\frac{L E}{L}\right)(86.4) \\
& E T=\left(\frac{28.3}{2,454}\right)(86.4)=1.00 \frac{\mathrm{mm}}{\text { day }}
\end{aligned}
$$

Step 9: Calculate the slope of the saturation vapor-pressure curve using equation 23 .

$$
\begin{gathered}
s=0.6112\left[\left(\left[\frac{17.67}{(T+243.5)}\right]-\left[\frac{17.67 T}{(T+243.5)^{2}}\right]\right)\right. \\
\left.\exp \left[\frac{17.67 T}{(T+243.5)}\right]\right]
\end{gathered}
$$

Using $T=20.74^{\circ} \mathrm{C}$ in the above equation gives

$$
s=0.1509 \frac{k P a}{{ }^{\circ} \mathrm{C}}
$$

Step 10: Calculate the saturated vapor pressure for $T=20.74^{\circ} \mathrm{C}$ using equation 20 .

$$
e_{s}=0.6112 \exp \left[\frac{17.67 T}{(T+243.5)}\right]=2.446 \mathrm{kPa}
$$


Step 11: Calculate the vapor pressure at $T=20.74^{\circ} \mathrm{C}$ and $h_{r}=65.35$ percent using equation 21 .

$$
e=e_{s}\left(0.01 h_{r}\right)
$$$$
e=(2.446)(0.01)(65.35)=1.598 k P a
$$

Step 12: Calculate the aerodynamic resistance to heat, $r_{h}$, using equation 25 .

$$
r_{h}=\frac{335}{u}=\frac{335}{1.393}=240 \frac{s}{m}
$$

Step 13: Calculate the canopy-resistance, $r_{c}$ using equation 18.

$$
\begin{aligned}
r_{c}= & \frac{r_{h}}{\gamma}\left(\frac{1}{L E}\left[s\left(R_{n}-G\right)+\left\{\frac{\rho_{a} C_{p}\left(e_{s}-e\right)}{r_{h}}\right\}\right]-s\right) \\
& -r_{h} \\
r_{c}= & \frac{240}{0.0630}\left(\frac{1}{28.3} 0.1509(113.4-10.0)\right. \\
& \left.\left.+\left(\frac{1.137(1.005)(2.446-1.598)}{240}\right)\right]-0.1509\right) \\
& -240=1,840 \frac{s}{m}
\end{aligned}
$$

Step 14: The canopy resistances calculated in Step 13 are used to formulate an average daily canopy resistance, shown in table 1 , which is used in this step. Calculate the latent-heat flux, (Penman-Monteith method), using equation 17 with the $r_{c}$ value for August 19 from table 1.

$1,790 \frac{s}{m}$

$L E=\left[\frac{s\left[R_{n}-G\right]+\left[\rho_{a} C_{p}\left(e_{s}-e\right)\right] / r_{h}}{s+\gamma\left[\left(r_{c}+r_{h}\right) / r_{h}\right]}\right]$

$L E=$

$$
\left(\frac{0.1509[113.4-10.0]+[1,137(1.005)(2.446-1.598)] / 240}{0.1509+0.0630[(1,790+240) 240]}\right)
$$

$L E=28.7 \frac{W}{m^{2}}$

Step 15: Calculate rate of evapotranspiration using (Penman-Monteith method) equation 15.

$$
\begin{aligned}
& E T=\left(\frac{L E}{L}\right)(86.4) \\
& E T=\left(\frac{28.7}{2,454}\right)(86.4)=1.01 \frac{\mathrm{mm}}{d a y}
\end{aligned}
$$

In the sample calculation, the result of each step is rounded off. However, in the computer calculations, the non-rounded result is used in the subsequent step. Therefore, results shown in this sample calculation may not exactly agree with results obtained with computer calculation. 